\title{
Pengaruh Budaya Organisasi terhadap Kompetensi Pustakawan (Studi Kasus pada Universitas Islam Indonesia Yogyakarta)
}

\author{
Sungadi \\ Universitas Islam Indonesia (UII) Yogyakarta
}

\begin{abstract}
The problem faced by the Library of Islamic University of Indonesia (UII) is still 70.37\% of librarians who have Diploma and Senior High School, so it is not in accordance with the existing standards, that is the qualification of university librarians with minimum education of Bachelor (S1) in Library Science. The purpose of this study is to determine the effect of organizational culture on the competence of UII librarians in living their profession. The subject of this research is UII Librarian as many as 27 people spread in several places, among others: in Directorate of UII Library, Faculty of Economics UII and Faculty of Law UII. During this time the librarian is still having difficulty in his career as a librarian, it is evident that almost every semester there are some librarians who get warning letter from UII leaders related to their obligation to apply DUPAK (List of Proposal of Credit Rate Submission). The research is intended to know the role of UII Library's organizational culture towards the development of librarian competence of UII. The results showed that the level of organizational culture UII Library and the level of competence Librarian UII perceived respondents in very high category with the respective perceptions of 81.76 and 84.25. There is a positive influence between organizational culture on the competence of Librarian UII with significance value $0.014<0.05(0.014)$ smaller than 0.05$)$. While the level of correlation between variables $X$ with variable $Y$ there is influence of $47.8 \%$ (0.478), where the value is in the classification is.
\end{abstract}

Keywords: $\quad$ organizational culture, library, competence, librarian, profession 


\section{Pendahuluan}

\section{Latar Belakang Masalah}

Pegawai Perpustakaan Universitas Islam Indonesia (UII) telah diakui sebagai pejabat fungsional pustakawan sejak tahun 1993 melalui impassing. Dalam perjalanannya banyak detemui kendala bagi pejabat fungsional pustakawan UII, mulai dari tingkat pendidikan pustakawan yang rendah, pangkat dan golongan, tim penilai angka kredit pustakakawan, pemahaman butir-butir kegiatan dan angka kredit, tata cara menyusun Daftar Usul Penetapan Angka Kredit (DUPAK), dan masih banyak masalah lainnya. Pendidikan para pustakawan UII saat itu hanya berijazah SLTA dan sederajat, sementara syarat minimal untuk menjadi pustakawan harus berpendidikan Diploma 2 bidang perpustakaan atau diploma 2 bidang lain yang telah disetarakan. Bahkan pada peraturan yang terdapat pada Standar Nasional Perpustakaan (SNP) ${ }^{1}$ Perguruan Tinggi Tahun 2011 dijelaskan bahwa kualifikasi pustakawan yang bekerja di Perpustakaan Perguruan Tinggi minimal harus berpendidikan Strata 1 (S1) bidang Ilmu Perpustakaan. Pangkat dan golongan pegawai perpustakaan UII pada tahun 1993 paling tinggi golongan II/c. Sampai sekarang untuk mengisi kekosongan tim penilai angka kredit pustakawan UII, diangkat pustakawan yang berasal dari perguruan tinggi lain. Sudah banyak upaya yang dilakukan oleh UII dalam rangka meningkatkan komptensi pustakawan, antara lain: pustakawan diberikan kesempatan melanjutkan studi formal (Diploma/D2/D3, dan Sarjana/S1). Sementara untuk memberikan bekal pengetahuan terhadap butir-butir kegiatan pustakawan dan tata cara penyusunan DUPAK bagi pustakawan UII telah banyak dilakukan diklat, dan workshop.

Pejabat fungsional pustakawan saat ini sudah mulai dikenal oleh masyarakat umum, dimana profesi pustakawan dari waktu ke waktu semakin memperlihatkan eksistensinya. Hal ini terbukti pada sebagaian pustakawan sudah tidak merasa sungkan dan malu lagi untuk menyebutkan jati dirinya

${ }^{1}$ Perpusnas RI. 2011. Standar Nasional Perpustakaan (SNP) Perguruan Tinggi Tahun 2011. (Jakarta: Perpusnas RI), hal. 6. 
sebagai pustakawan. Eksistensi pustakawan telah dibuktikan dengan telah diterbitkan SK-MENPAN 132 tahun 2002 yang diperbaharui dengan PERMENPAN \& RB RI No. 9 tahun 2014 yang mengatur kinerja pustakawan terkait dengan profesi pustakawan dan angka kredit. Adanya peraturan ini, akses status dan pengakuan serta penghargaan akan lebih mudah diperoleh bagi para pustakawan baik akses ke masyarakat maupun pemerintah.

Permasalahan yang dihadapi UII saat ini adalah dari keseluruhan pustakawan yang dimiliki UII sebanyak 27 orang, masih terdapat $9(33,33 \%)$ orang yang diangkat melalui inpassing berpendidikan SLTA. Sementara pustakawan UII yang berlatar pendidikan diploma sebanyak 10 orang (37,04\%). Dari penjelasan ini dapat dipahami bahwa jumlah pustakawan UII yang belum memenuhi standar (SNP-2011) sebesar 70,37\%.

Mengacu pada permasalahan tersebut, maka perlu dilakukan penelitian lebih lanjut terkait dengan pengaruh budaya organisasi terhadap kompetensi Pustakawan UII Yogyakarta.

\section{Rumusan Masalah}

Berangkat dari uraian latar belakang di atas, maka peneliti mengambil tema studi tentang pengaruh budaya organisasi terhadap kompetensi Pustakawan UII Yogyakarta. Oleh karena itu permasalahan dalam penelitian ini ada 2 rumusan deskriptif dan 1 rumusan masalah asosiatif, yaitu:

a. Bagaimana tingkat kualitas budaya organisasi (X) pada Perpustakaan UII?

b. Bagaimana tingkat kualitas kompetensi (Y) pustakawan UII?

c. Adakah pengaruh tingkat kualitas budaya organisasi terhadap kompetensi pustakawan UII dalam menjalani profesinya?

\section{Tujuan}

Tujuan penelitian ini adalah dalam rangka untuk menganalisis:

a. Kondisi budaya organiasi (X) pada Perpustakaan UII Yogyakarta.

b. Kondisi kompetensi (Y) pustakawan UII. 
c. Apakah kualitas budaya organiasi (X) berpengaruh terhadap kompetensi pustakawan (Y) pada Perpustakaan UII Yogyakarta.

\section{Manfaat}

Pada akhir riset ini diharapkan hasilnya akan dapat memberikan kontribusi bagi pengembangan kompetensi pustakawan dan Perpustakaan UII diantaranya :

a. Sebagai bukti ilmiah seberapa besarkah tingkat kompetensi pustakawan UII dalam menjalani profesinya.

b. Dapat digunakan sebagai rujukan bagi para pustakawan UII agar dapat lebih meningkatkan kompetensinya dalam menjalani profesi sebagai pustakawan, sehingga kinerjanya diharapkan juga meningkat.

c. Sebagai input bagi Perpustakaan UII dan rujukan bagi periset di waktu yang akan datang pada kajian ranah budaya organisasi dan kompetensi dalam mengelola budaya organisasi bagi perpustakaan serta mengembangkan kompetensi bagi pustakawan dalam menjalani profesinya.

\section{Hipotesis}

Berdasarkan permasalahan dan tujuan yang telah diuraikan tersebut, dapat dibuat hipotesis terdapat pengaruh positif yang substansial antara budaya organisasi terhadap kompetensi pustakawan UII.

\section{Kajian Teori}

\section{Budaya Organisasi}

\section{Defenisi dan Konsep Budaya Organisasi}

Menurut literatur-literatur dalam bahasa Inggris kontribusi budaya terhadap organisasi pertama kali diperkenalkan pada tahun 1960-an: dimana budaya organisasi adalah sinonim dari iklim/suasana organisasi. Baru kemudian mulai populer sebagai "Budaya Perusahaan" pada sekitar tahun 1970-an, kemudian semakin melejit pada tahun 1982 setelah munculnya buku 
Corporate Culture oleh Deal and Kennedy (Hostede, 2005:281)2. Kemudian menjadi istilah yang semakin lazim digunakan melalui kesuksesan dua orang peneliti dari McKinsey - Harvard Business School Team: yaitu Peters dan Waterman dalam bukunya yang berjudul In Search of Excellence, yang diterbitkan pada tahun yang sama. Setelah itu semakin banyak ditemukan literatur-literatur mengenai budaya organisasi dalam berbagai bahasa.

Deal and Kennedy (2001:4) mengatakan budaya organisasi adalah nilai-nilai, mitos, kepahlawanan, dan simbol-simbol yang menjadi spirit (penyemangat) bagi individu-individu yang bekerja didalam suatu organisasi. Budaya organisasi menurut webter's new collegiate dictionary (dalam Deal and Kennedy, 2001:4) ${ }^{4}$ adalah perpaduan pola perilaku manusia yang meliputi ide-ide/gagasan, ucapan, dan tindakan berdasarkan kemampuan dalam menjalani proses pembelajaran dan penyampaian ilmu pengetahuan secara terus menerus.

Mengapa kita bekerja? Karena uang, konsep umum yang berlaku mengatakan seperti itu. Namun dalam suatu organisasi yang memiliki budaya yang menyatu erat dengan organisasi tersebut, pegawai menjawab mereka bekerja karena megetahui dengan jelas visi dan misi perusahaan/lembaga tempat dimana mereka bekerja, sehingga mereka bekerja karena termotivasi visi dan misi lembaga tersebut.

Schein (1985:12) $)^{5}$ menyatakan yang terjemahan bebasnya kurang lebih bahwa budaya organisasi adalah satu perangkat nilai, keyakinan, dan pandangan hidup organisasi yang dijiwai, dipahami dan dipraktekkan oleh semua anggota organisasi dan diajarkan kepada pegawai baru pada institusi sebagai media sahih untuk bertindak dan kesepakatan yang diikuti dan menjadi tuntunan bagi anggotanya dalam bertindak.

2 Jan G. Hofstede. Cultures and Organizations (Sofware of The Mind): Intercultural Cooperation and its Importance for Survival. (New York: McGraw-Hill, 2005), hal. 281.

${ }^{3}$ Terrence E. Deal and Alland A. Kennedy. Corporate Cultures: The Rites and Rituals of Corporate Life. (New Jersey: Addison-Wesley Publishing Company Inc., 2001), 4.

${ }^{4}$ Ibid.hal. 4.

${ }^{5}$ E.H. Schein. Organizational Culture and Leadership. (San Francisco: Jossey Bass Inc., 1985), hal. 12. 
Budaya Organisasi atau Corporate Culture sering diartikan sebagai norma-norma, ikon-ikon yang dipahami dan ditaati berbareng, yang dipunyai sebuah perusahaan sehingga komunitas organisasi tersebut merasa satu rasa satu karsa sehingga keeratan dan kebersamaan dapat dijalin dengan akrab. Pendapat ini sejalan dengan Robbins (2001:308) ${ }^{6}$ yang menyebutkan bahwa budaya organisasi merupakan persepsi berbareng yang diikuti oleh komunitas institusi itu, suatu sistem dari makna bersama.

Menurut pendapat Schein $(1985: 168)^{7}$, budaya perusahaan mengacu suatu sistem makna bersama dianut oleh anggota-anggotanya yang membedakan organisasi itu terhadap organisasi-organisasi lain. Setiap organisasi, sebagian dibentuk melalui proses budaya yang terbentuk oleh keragaman pelaku-pelaku lingkungan. Namun demikian, sumber daya yang paling besar terhadap pengaruh luar pada budaya organisasi yang ditemukan di dalam organisasi pegawainya. Pegawai telah mendapatkan pengaruh sebelumnya melalui lingkungan keluarga, warga kemasyarakatan: RT, RW, Pedukuhan, dan lainnya, lingkungan jamaah masjid, dan bentuk organisasi lainnya sebelum pegawai tersebut bergabung dengan organisasi yang baru, sehingga mereka sebelumnya sudah memiliki etika, norma, karakter, sikap, identitas, dan perilaku. Karyawan akan memberikan kekuatan tersebut bersamanya pada saat bergabung di institusi itu.

Ketika para pegawai berinteraksi dalam suatu institusi, mereka memberikan ajaran dan keyakinan yang sudah ditanamkan terhadap mereka. Namun acap kali yang terjadi, ajaran dan keyakian tersebut kurang memberi manfaat bagi pegawai yang bersangkutan untuk sukses dalam organisasi karena kurangnya perhatian terhadap nilai-nilai yang diajarkan tersebut. Mereka perlu belajar bagaimana organisasi tersebut melakukan aktivitasnya. Pada umumnya mereka diberikan pelatihan untuk menata kembali cara berpikir. Yang bersangkutan dilatih untuk merenungkan dan berperan sebagaimana yang diinginkan oleh institusi tersebut.

${ }^{6}$ Stephen P. Robbins. (terjemahan Tim Indeks), Perilaku Organisasi, Edisi 9, Jilid 2. (Jakarta: PT Indeks Kelompok Gramedia: 2001), hal. 308.

${ }^{7}$ Ibid Schein. Organizational Culture and Leadership, hal. 168. 
Institusi membuat regulasi yang memiliki ciri khusus sehingga berbeda dengan lembaga yang lain, yang meliputi berbagai norma, etika, dan segala tingkah laku sehingga komunitas yang tergabung pada lembaga dapat berinteraksi dan beraktivitas sesuai dengan budaya dan etika yang ada di lembaga tersebut.

Lebih lanjut Schein ${ }^{8}$ menjelaskan, secara mendalam bahwa, tradisi/ norma pada badan/lembaga diartikan sebagai aturan pokok atau alat organisasi yang dipakai sebagai landasan serta acuan dalam memecahkan berbagai persoalan dan problem yang meungkin terjadi di dalam lembaga itu. Masalah itu merupakan perkara yang cukup berharga, oleh karena itu sudah seharusnya apabila norma, etika, dan aturan dasar itu perlu diajarkan dan dimengerti oleh komunitas yang terhimpun pada lembaga tersebut.

Islam mengajarkan dan menganjurkan adanya persatuan, kebersamaan dan keteraturan, kebersihan, menjahui perpecahan, cerai berai, dan ketidak teraturan. Sebagaimana yang disebutkan dalam Al Quran, yang artinya:

"Dan berpeganglah kamu semuanya kepada tali (agama) Allah, dan janganlah kamu bercerai berai, dan ingatlah akan nikmat Allah kepadamu ketika kamu dahulu (masa Jahiliyah) bermusuh-musuhan, Maka Allah mempersatukan hatimu, lalu menjadilah kamu Karena nikmat Allah, orang-orang yang bersaudara; dan kamu Telah berada di tepi jurang neraka, lalu Allah menyelamatkan kamu dari padanya. Demikianlah Allah menerangkan ayat-ayat-Nya kepadamu, agar kamu mendapat petunjuk. ${ }^{9}$ Pada ayat lain, Allah Ta'ala berfirman, yang artinya: Dan janganlah kamu menyerupai orang-orang yang bercerai-berai dan berselisih sesudah datang keterangan yang jelas kepada mereka. mereka itulah orang-orang yang mendapat siksa yang berat."10

Persatuan dan kekompakan menjadi pangkal kekuatan dan keberhasilan dalam sebuah organisasi, sebaliknya perselisihan dan perpecahan menjadi pangkal kelemahan dan kekalahan. Sebagai mana sabda Nabi Muhammad SAW, yang artinya:

“...Wajib atas kalian untuk bersama dengan al-jamaah dan berhati-hatilah kalian dari perpecahan. Sesungguhnya setan bersama orang yang sendirian, sedangkan dari orang yang berdua dia lebih jauh. Barangsiapa yang menginginkan tengah-tengahnya (yang terbaiknya) surga maka hendaklah dia bersama jamaah. Barangsiapa yang kebaikan-

\footnotetext{
${ }^{8}$ E.H. Schein. Organizational Culture and Leadership, hal. 15

${ }^{9}$ Quran Surat Ali Imran ayat 103.

${ }^{10}$ Ibid ayat 105.
} 
kebaikannya menggembirakan dia dan kejelekan-kejelekannya menyusahkan dia, maka dia adalah seorang mukmin." (Shahih, diriwayatkan oleh At-Tirmidzi).

Telah disepakati bahwa diantara tafsir di atas mengalamai keselarasan tidak ada perbedaan diantara tafsir satu dengan tafsir yang lainnya. Sebab memberikan landasaan agar umat Islam saling berpedoman pada ajaran Islam secara kaffah berlandaskan Quran dan Hadits Nabi Muhammad SAW. Disamping itu perlu dijaga kebersamaan dan menyamakan visi dan misinya diantara komunitas lembaga berjalan selaras dengan para pimpinan organisasi tersebut. Diantara komunitas yang tergabung dalam lembaga tersebut juga diperintahkan untuk menjaga persatuan dan tidak berpecah belah. Islam sangat menekankan perkumpulan dan kebersamaan, tidak ada ibadah tanpa perkumpulan, shalat berjama'ah lebih tinggi nilainya daripada shalat sendiri, ibadah zakat kebersamaan antara orang kaya dengan orang miskin yang diorganisir oleh lembaga Amil Zakat, ibadah haji merupakan pertemuan tahunan umat Islam sedunia.

Menurut hemat peneliti, pengertian di atas sedemikan berbeli-belit sehingga budaya organisasi cukup diartikan sebagai aturan dasar yang harus ditaati bersama antara anak buah, pimpinan, dan semua kelompok yang tergabung di organisasi tersebut.

\section{Karakteristik Budaya Organisasi}

Menurut Robbins (Pabundu Tika 2006:10) ${ }^{11}$, ada 10 ciri khusus yang dapat dipakai sebagai acuan untuk mengukur eksistensi budaya organisasi sehingga akan memudahkan untuk memahaminya,yaitu:

1) Prakarsa Personal, menyangkut kebebasan berinisiatif, berpendapat, mengemukakan ide, dan berkarya yang dilandasi dengan penuh rasa tanggung jawab demi kemajuan lembaga.

2) Adanya tenggang rasa, toleransi, tasamuh dalam menghadapi tantangan, resiko pada setiap tindakan inovatif, dan agresif yang dilakukan oleh setiap anggota yang terhimpun dalam organisasi itu.

${ }^{11}$ Pabundu Tika. Budaya Organisasi dan Peningkatan Kinerja Perusahaan. (Jakarta : PT. Bumi Aksara. 2006) hal. 10. 
3) Adanya arahan yang jelas bagi para pegawai, sehingga visi, misi, tujuan, dan sasaran lembaga dapat tercapai sesuai yang diharapkan bersama.

4) Terciptanya integrasi terhadap unit-unit yang ada di sebuah organisasi agar tercipta kerjasama yang solid sehingga hasil kerja secara kuantitas dan kualitas dapat tercapai dan terlampaui.

5) Suport penuh dari pimpinan dan manajer terhadap bawahan sehingga terjalin komunikasi dua arah yang harmonis sehingga pekerjaan dapat berjalan secara lancar.

6) Pengawasan melekat berupa atura-aturan dan norma-norma yang diberlakukan pada lembaga tersebut sehingga berbagai kegiatan, perilaku, dan aktivitas para pegawai dapat terkendali dan terawasi dengan baik.

7) Personalitas dan jati diri pegawai yang diwujudkan dalam bentuk identitas diri (misal dalam bentuk kartu pegawai) yang dalam hal ini sebagai atas nama kesatuan kerja buka atas nama perorangan atau kelompok unit tertentu.

8) Metode/pola penggajian dimaksudkan model yang bagaimana dan seperti apa mekanisme pemberian imbalan dan pembayaran upah atau gaji (penjenjangan pangkat/golongan ruang gaji, kenaikan upah, lembur, tunjangan jabatan, penghargaan bagi yang berprestasi khusus, dan lainlain).

9) Open management dimaksudkan adanya keterbukaan bagi organisasi terhadap kritik dan saran dari insan yang tergabung pada lembaga tersebut, serta adanya open informasi bagi para pegawai. Adanya perbedaan pendapat merupakan bentuk dinamisasi organisasi dalam rangka untuk menyamakan visi dan misi organisasi.

10) Sistem hubungan korespondensi dan komunikasi antar pimpinan dengan bawahan, komunikasi antar sesama pegawai perlu dibangun secara harmonis, sehingga hubungan diantara mereka tidak ada jarak yang membatasinya.

Dari ke 10 ciri khusus tersebut, menurut hemat peneliti masih perlu ditambahkan ciri khas bagi organisasi yang bernuansa Islam misalnya adanya 
budaya organisasi berupa: gerakan shalat berjamaah di masjid pada saat di kantor, membaca Al Quran sebelum memulai pekerjaan, melakukan shalat dhuha sebelum berangkat kerja atau pada saat sudah tiba di kantor, dan lain-lain.

\section{Peran Budaya Organisasi}

Robbins (2009:589) ${ }^{12}$ memberikan penjelasan terkait peran budaya organisasi antara lain:

Membuat 'merek' khusus agar organisasi memiliki ciri khusus sehingga berbeda dengan organisasi lain.

1) Menciptakan rasa bangga bagi anggota organisasi sehingga mereka loyal teradap organisasi.

2) Terciptanya keterikatan pada organisasi bagi setiap anggota sehingga melahirkan rasa tasamuh, dan mengutamakan kepentingan organisasi dari pada kepentingan pribadi.

3) Membuat strata sosial, sehingga terjalin hubungan sosial yang erat diantara para anggota organisasi yang pada akhirnya akan tercipta rasa persatuan dan kebersamaan. Didalam strata sosial perlu dibuat aturanaturan dan norma-norma mana yang pantas dan tidak pantas untuk dilakukan oleh pegawai.

4) Berfungsi sebagai alat kontrol bagi pegawai, sehingga sikap dan perilaku pegawai dapat terawasi dengan baik.

Budaya organisasi memiliki kekuatan secara substansional yang membawa para pegawai memiliki tatakrama, sopan santun, etika pergaulan, saling menghargai diantara sesama pegawai, sehingga terjalin hubungan yang harmonis bagi komunitas pada organisasi tersebut. Budaya organisasi mempunyai tanggung jawab terhadap tingkah laku bagi para pegawainya sehingga tercipta nuansa agamis sesuai keyakinan bagi para pegawai, penuh kedamaian, keakraban, ketenteraman, dan lain-lainnya.

${ }^{12}$ Stephen P. Robbins. Organizational Behavior, 13rd ed. (New Jersey: Prentice Hall: 2009), 
Salah satu bukti mutakhir yang terkenal adalah hasil penelitian Kotter and Hessket yang dilakukan antara Agustus 1987 sampai Januari 1991 tehadap 22 perusahaan dengan sektor industri berbeda di USA (Supardi, 2006:72) ${ }^{13}$, dan mempublikasikannya melalui Harvard Business School. Hasilnya membuktikan bahwa budaya memiliki pengaruh dan efek yang signifikan atas kinerja korporate. Studi itu menyimpulkan beberapa hal penting antara lain bahwa, budaya organisasi:

1) Memiliki kekuatan yang substansional dan penting atas kinerja organisasi dalam jangka lama.

2) Memiliki peran penting dalam menghantarkan organisasi berhasil atau tidaknya di waktu-waktu yang akan datang.

3) Mengantarkan sistem finansial berkekuatan besar dalam kurun waktu yang lama, dan menjadikan tumbuh kembangnya organisasi seiring dengan insan-insan yang arif dan cerdas yang berakhlak mulia.

4) Meskipun berat, budaya organisasi mampu menciptkan kinerjanya lebih unggul dalam meraih kesuksesan.

\section{Aspek Budaya Organisasi}

Robbins (2009: 585) ${ }^{14}$ memberikan 7 ciri khas aspek utama yang secara asosiasi menangkap esensi budaya organisasi, yaitu:

1) Kreatif dan mampu berspekulasi, dimana para pegawai mempunyai terobosan baru dan berani menghadapi tantangan maupun risiko.

2) Fokus terhadap perkara yang lebih detail, harapannya para pegawai memiliki kemampuan menganalisis segala sesuatu secara mendalam dan rinci.

3) Fokus terhadap prestasi, organisasi perlu mendidikan pegawainya agar mampu berprestasi dalam bekerja.

4) Fokus kepada personal, dimana organisasi mampu memberikan motivasi

${ }^{13}$ Supardi. Pengaruh Budaya Organisasi terhadap Keadilan Distributif dan Keadilan Prosedural, serta Produktivitas Kerja Pegawai Hotel Berbintang di Daerah Istimewa Yogyakarta. Disertasi. (Surabaya: Program Pascasarjana Airlangga, 2006). hal. 72.

${ }^{14}$ Ibid Robbins. Organizational Behavior, $13^{\text {rd }}$ ed. hal. 585. 
terhadap pegawai sehingga masing-masing individu memiliki prestasi kerja secara pribadi bukan atas hasil kerja sama.

5) Fokus kepada satuan kerja/kelompok, dimana organisasi mampu memberikan motivasi terhadap kelompok kerja pegawai sehingga secara kolektif mereka mampu berprestasi atas hasil kerja sama.

6) Sifat agresif, dimana organisasi mampu membangun semangat bagi para pegawai agar mampu berkompetisi dan bersaing secara positif.

7) Kemantapan, hal ini dimaksukan agar organisasi mampu menciptakan sifat loyalitas pegawai sehingga memiliki rasa memiliki terhadap organisasi.

Dari 7 aspek penting tersebut nyatalah bahwa dimensi budaya organisasi merupakan sebuah pilar terstruktur dari arah bawah menuju ke atas. Tujuh dimensi budaya organisasi akan diraih potret heterogen yang menjadi dasar dalam pemahaman bersama agar pekerjaan kantor dapat diselesaikan secara individu maupun secara kelompok.

\section{Kompetensi}

\section{Pengertian dan Dimensi Kompetensi}

Kompetensi menyangkut kecakapan, kebolehan, kemampuan, skill, kapabilitas, kepintaran, dan lain-lain bagi seseorang dalam melaksanakan pekerjaan yang menjadi wewenang dan tanggung jawabnya, sehingga sesuatu urusan dapat diselesaikan secara maksimal dan hasil yang unggul.

Spenser dan Spenser dalam Moeheriono (2010:3) ${ }^{15}$ menyatakan bahwa kapabilitas adalah ciri khusus insan yang erat hubungannya dengan kemampuan bekerja sesuai dengan keahlian, skill, dan kemampuan yang dimilikinya sehingga memperoleh hasil kerja yang memuaskan. Dari pengertian di atas dapat dipahami bahwa:

1) Karateristik pokok (underlyng characteristics) kompetensi adalah sifat pribadi yang dimiliki pegawai sehingga mampu memprediksi tugasnya akan dapat diselesaikan secara sempurna dengan berbagai risiko dan

\footnotetext{
${ }^{15}$ Moeheriono. (2010). Pengukuran Kinerja Berbasis Kompetensi. (Bogor: Ghalia Indonesia), 3.
} 
keadaan.

2) Relasi sebab akibat, dimana kompetensi mampu membaca kemampuan kerja seseorang, maksudnya kompetensi mampu memaknai bahwa jika pegawai mempunyai kompetensi unggul, maka pegawai itu mampu bekerja dengan hasil unggul.

3) Rujukan kualifikasi (qualification referrals) yang digunakan untuk rujukan, bahwa kompetensi mampu membaca personal berkinerja unggul dan berkualitas menurut ukuran dan prosedur yang telah ditetapkan.

Lebih lanjut Spencer dan Spencer dalam Sutrisno $(2011: 206)^{16}$ mengemukakan karateristik kompetensi terdapat lima aspek, yaitu :

1) Motivasi, merupakan adanya dorongan dan keuatan yang datangnya dari dalam diri individu untuk melakukan aktivitas atau pekerjaan. Misal dorongan atau keiningian untuk mulai kerja, keinginan untuk maju, ingin berprestasi, ingin segera lulus sekolah, ingin karir berkembang, dan seterusnya.

2) Karakter atau sifat, merupakan akhlak dan kepribadian seseorang dalam bertingkah laku. Contoh: sifat pemalu, sifat penyayang, sifat pemberani, penyabar, pemarah, sifat santun dan terpuji, dan lain-lainnya.

3) Konsep diri, merupakan potret diri seseorang yang melukiskan atau menggambarkan nilai kepribadian yang diukur melalui uji kompetensinya. Contoh: seorang pekerja keras mempunyai potensi untuk meraih kematangan karir.

4) Pengetahuan (knowledge), kemampuan secara intelektual yang dipunyai seseorang sehingga mampu menyelesaikan tugas dan pekerjaan melalui prosedur yang telah ditetapkan.

5) Skills dan ketrampilan, dimana secara teknis seorang pegawai mampu menjalankan tugas secara tuntas. Contoh: seorang pustakawan dalam mengembangkan karir perlu memiliki skill dan ketrampilan membuat karya tulis ilmiah dan meneliti dengan baik dan benar serta berkelanjutan.

${ }^{16}$ Edi Iswanto Sustrisno. 2011. Manajemen Sumber Daya Manusia.(Jakarta: Kencana), 206. 
Menurut Gordon dalam Sutrisno (2011:204) ${ }^{17}$, di dalam kompetensi terdapat 6 dimensi antara lain:

1) Pengetahuan (knowledge) adalah kemampuan secara intelektual yang dipunyai seseorang sehingga mampu menyelesaikan tugas dan pekerjaan melalui prosedur yang telah ditetapkan. Contoh: seorang pustakawan memiliki kemampuan untuk memberikan bimbingan terhadap pemakai, bagaimana cara mendapatkan sumber-sumber informasi secara cepat melalui OPAC, internet, atau kartu katalog. Conton lainnya, pustakawan mampu membuat konsep dan program kerja dalam rangka pengembangan perpustakaan, baik program kerja jangka pendek, menengah, maupun jangka panjang. Pustakawan mampu mengembangkan profesi sehingga dapat meraih kenaikan pangkat dan jabatan fungsional secara reguler sesuai dengan kurun waktu yang sudah dijadwalkan, misalnya setiap 2 tahun mampu naik pangkat dan jabatan fungsional sebagai pustakawan.

2) Pemahaman (understanding), yaitu kedalaman psikologis (cognitive) dan afektif (makna emotif) yang dipunyai seseorang. Contoh: seorang pustakawan perlu memiliki pemahaman dengan baik terhadap lingkungan kerja dan budaya organisasi sehingga tidak salah dalam bersikap dan bertindak.

3) Kemampuan (skill), dimana secara teknis seorang pustakawan mampu menjalankan tugas dan wewenangnya secara tuntas sesuai SOP yang ada. Contoh: seorang pustakawan mampu memberikan layanan kepada pemustaka sesuai dengan standar dan prosedur, mampu melakukan pengolahan koleksi, menjalankan shelving dengan benar, dan mampu membuat karya tulis ilmiah dengan baik dan benar serta berkesinambungan.

4) Nilai-nilai (values) adalah kemampuan seseorang dalam menjalani karir sesuai dengan kaidah dan aturan baku yang telah disepakati bersama. Contohnya: mengucapkan salam kepada sahabat, teman, pimpinan, pemustaka ketika berjumpa. Melakukan shalat fardlu secara berjamaah di masjid atau mushalla, memulai dan mengakhiri pekerjaan dengan

\footnotetext{
${ }^{17}$ Edy Sustrisno. Manajemen Sumber Daya Manusia. (Jakarta: Kencana, 2011), hal. 204.
} 
berdoa. Disamping itu norma secara umum yang harus ditaati oleh setiap pegawai adalah adanya sifat keterbukaan, kejujuran, menjalankan aturan secara konsisten, menghormati yang lebih tua, mau menolong kepada yang membutuhkan, dan lain-lain.

5) Tingkah laku (attitude), adalah tabiat dan perilaku yang mencerminkan sifat seseorang, contohnya kematangan jiwa seseorang secara emosi dan spiritual sehingga mampu menghadapi persoalan secara arif dan bijaksana.

6) Minat (interest) merupakan motivasi seseorang untuk memilih suatu pekerjaan atau profesi yang akan dijalaninya. Contohnya minat menjadi pustakawan akan dimulai dari pilihan jalur pendidikan yang sejalan dengan profesi itu, yaitu memilih jurusan ilmu perpustakaan, dan seterusnya.

Dari penjelasan di atas dapat digaris bawahi bahwa kompetensi, merupakan modal dasar yang harus dimiliki bagi seseorang sehingga mampu menyelesaikan pekerjaan yang menjadi tugas dan wewenangnya. Modal dasar tersebut berupa motivasi, minat, pengetahuan, pemahaman, values, skill, pemahaman, dan ketrampilan.

\section{Kompetensi Pustakawan}

Selaras dari penjelasan sebelumnya Standar Kompetensi Kerja Nasional Indonesia (SKKNI) Nomor 83 Tahun 2012 Bidang Perpustakaan, pada Bab I menjelaskan bahwa kompetensi adalah merupakan modal dasar yang harus dimiliki bagi seseorang berupa motivasi, minat, pengetahuan, pemahaman, values, skill, pemahaman, dan ketrampilan sehingga mampu menyelesaikan pekerjaan yang menjadi tugas dan wewenangnya. ${ }^{18}$

Dari pengertian yang dirumuskan oleh SKKNI tersebut dapat dijabarkan lebih lanjut bahwa, kompetensi yang harus dimiliki pustakawan adalah meliputi pekerjaan intelektual dan pekerjaan ketrampilan. Pekerjaan intelektual, misalnya seorang pustakawan mampu membuat program

${ }^{18}$ Perpusnas RI, 2012. Standar Kompetensi Kerja Nasional Indonesia (SKKNI) Nomor 83 Tahun 2012 Bidang Perpustakaan. (Jakarta: Perpusnas RI), Bab I, hal 2. 
kerja perpustakaan, mampu mengembangkan sistem perpustakaan, pengembanagan koleksi, mampu membuat laporan, mampu melakukan evaluasi terhadap hasil kinerja perpustakaan, mampu melakukan penelitian dan menulis karya ilmiah, dan lain-lain). Sementara kompetensi yang terkait dengan ketrampilan meliputi: pengolahan bahan perpustakaan, melayani pemakai, memandu pemakai dalam mencari dan menemukan sumber-sumber informasi secara efektif dan efisien, pemeliharaan koleksi, pengelolaan jajaran koleksi di rak, dan lain-lain.

\section{Dimensi dan Indikator Kompetensi}

Berikut ini disajikan dalam bentuk tabel dimensi dan indikator kompetensi:

Tabel 1 Dimensi dan Indikator Kompetensi

\begin{tabular}{|c|c|c|c|}
\hline \multirow{2}{*}{$\frac{\text { No }}{1}$} & \multirow{2}{*}{$\begin{array}{r}\text { Dimensi } \\
\text { Pengetahuan } \\
\text { (Knowledge) }\end{array}$} & \multicolumn{2}{|c|}{ Indikator } \\
\hline & & $\begin{array}{l}\text { 1. Menguasai teori yang berhubungan } \\
\text { dengan bidang kerja secara memadai. } \\
\text { 2. Mengetahui dan menguasai prosedur } \\
\text { kerja dan aturan lainya terkait dengan } \\
\text { proses penyelesaian pekerjaan. }\end{array}$ & $\begin{array}{l}\text { 3. Mempunyai pengetahuan bidang } \\
\text { kepustakawanan yang memadai. } \\
\text { 4. Dapat berpikir kreatif dalam } \\
\text { melaksanakan pekerjaan } \\
\text { 5. Dapat memberikan ide yang baik } \\
\text { dalam bekerja }\end{array}$ \\
\hline 2 & $\begin{array}{l}\text { Pemahaman } \\
\text { (Understanding) }\end{array}$ & $\begin{array}{l}\text { 1. Mampu menjalin kerja sama secara } \\
\text { baik dengan kerabat kerja. } \\
\text { 2. Memiliki problems sholving terhadap } \\
\text { pekerjaan. }\end{array}$ & $\begin{array}{l}\text { 3. Mampu berkomunikasi secara baik ter- } \\
\text { hadap kerabat kerja. }\end{array}$ \\
\hline 3 & $\begin{array}{l}\text { Kemampuan } \\
(\text { Skill })\end{array}$ & $\begin{array}{l}\text { 1. Mampu menyelesaiakan pekerjaan } \\
\text { dengan kualitas prima. }\end{array}$ & 2. Memiliki rasa tanggung jawab tinggi. \\
\hline 4 & Nilai (Value) & $\begin{array}{l}\text { 1. selalu melaksanakan pekerjaan } \\
\text { tepat waktu }\end{array}$ & $\begin{array}{l}\text { 2. Dapat mematuhi norma-norma so- } \\
\text { sial dalam melaksanakan pekerjaan }\end{array}$ \\
\hline 5 & Sikap (Attitude) & $\begin{array}{l}\text { 1. dapat menyelesaikan pekerjaan sesuai } \\
\text { dengan prosedur } \\
\text { 2. selalu hadir tepat waktu }\end{array}$ & $\begin{array}{l}\text { 3. Taat dan tunduk terhadap semua relu- } \\
\text { gasi yang ada. }\end{array}$ \\
\hline 6 & Minat (Interest) & 1. Berkeinginan untuk maju & 2. Mantap dalam menjalani profesi \\
\hline
\end{tabular}

Sumber: Gary Dessler. (2000)

Dari pengertian dan uraian tersebut dapat diberikan penjelasan tambahan bahwa kompetensi pustakwan yang meliputi pengetahuan, keterampilan, dan sikap kerja pustakawan dalam menyelesaikan pekerjaannya harus terstruktur dan terukur sesuai dengan standar yang berlaku. Penjelasan lebih lanjut oleh Permenpan No.09 Tahun 2014 bahwa kompetensi 
pustakawan diukur dan dinilai dari 6 (enam) dimensi, yakni: pendidikan formal dan non formal, pengorganisasian (manajemen) perpustakaan, pelayanan pemakai dan teknis perpustakaan, pengembangan sistem kepustakawanan, pengembangan profesi, dan kegiatan penunjang pustakawan.

Keenam dimensi tersebut yang kemudian membentuk kompetensi pustakawan untuk selanjutnya dapat mempengaruhi performa kematangan karir.

\section{Metode Penelitian}

1. Tempat dan Waktu Penelitian

Riset diselenggarakan di Universitas Islam Indonesia Yogyakarta. Pemilihan lokasi penelitian ini dengan pertimbangan: masalah yang dikaji terdapat di Universitas Islam Indonesia, dan dalam rangka hemat biaya, waktu dan tenaga. Riset diselenggaran pada bulan Mei - Juni 2018.

2. Populasi, Sampel dan Model Penentuan Sampel

Dalam penelitian ini yang dimaksud dengan populasi adalah pustakawan yang bertugas di lingkungan UII sebagai subyek penelitian. Dari hasil survey awal yang bersumber dari data kepegawaian Direktorat Perpustakaan UII tahun 2017, diperoleh data bahwa pustakawan UII saat ini sejumlah 26 orang. Peneliti mengambil seluruh populasi (sensus) untuk dijadikan subyek penelitian.

3. Teknik Pengumpulan Data

Penghimpunan data dilakukan melalui penyebaran angket kepada pustakawan yang bertugas di lingkungan kampus UII.

4. Teknik Analisis Data

Sesuai dengan tujuan riset, data yang terhimpun akan dikaji secara deskriptif kuantitatif yaitu dengan memaparkan data-data yang ada sedetail mungkin dengan memvisualiasikan ke dalam sebuah tabel, kemudian dilakukan analisis data dengan korelasi Product Moment berbantuan program SPSS, selanjutnya dilakukan pembahasan secara keseluruhan sehingga dapat diketahui dan dianalisis, kemudian dapat 
ditarik suatu kesimpulan dengan melalui beberapa tahapan antara lain:

Dari hasil hitungan persepsi responden tersebut, akan ditentukan 3 kategori, antara lain: rendah, sedang, dan atau tinggi. Di bawah ini digambarkan kerangka analisis data:

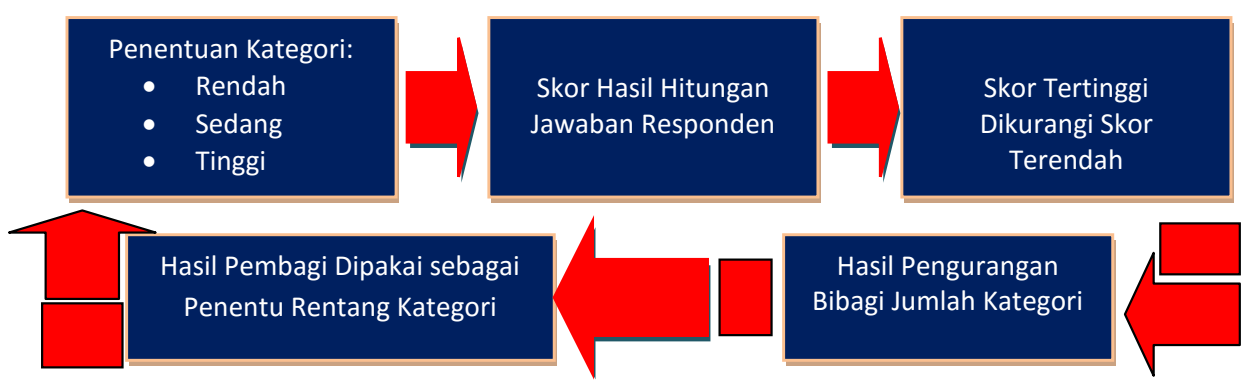

Gambar 1: Kerangka Analisis Data Deskriptif
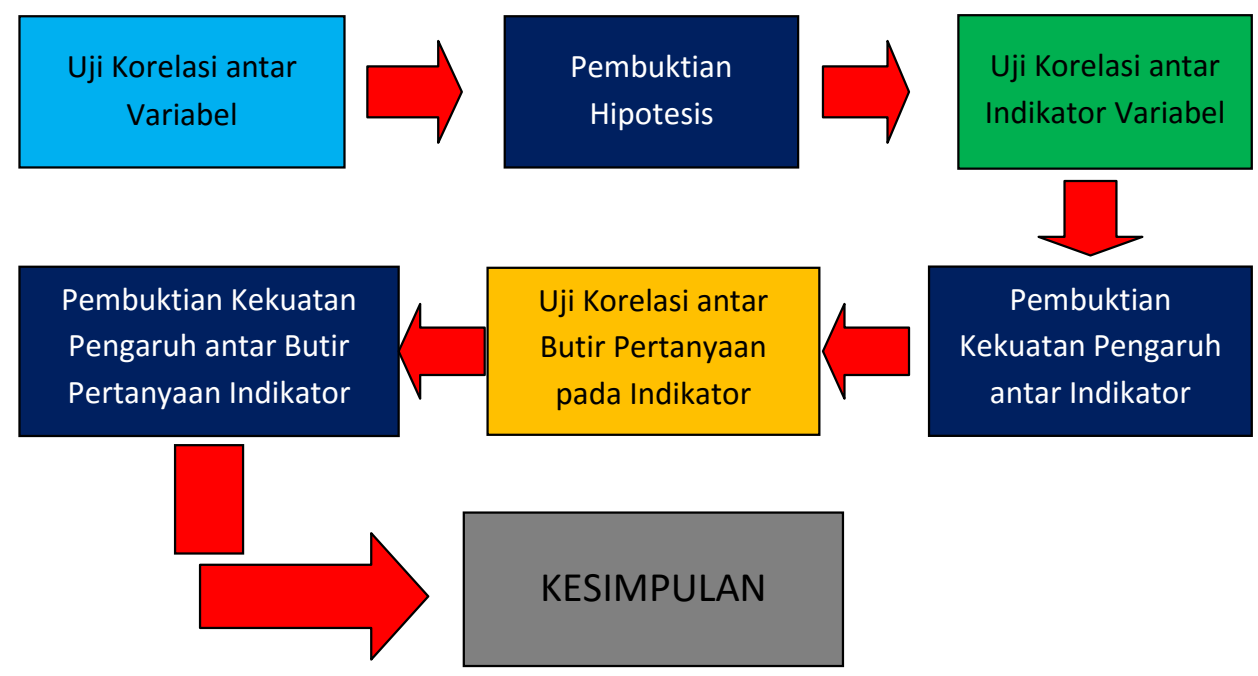

Gambar 2: Kerangka Analisis Data Asosiatif

Dari hasil analisis data asosiatif akan diketahui bahwa:

a. Uji antar variabel: ada tidaknya pengaruh antara variabel budaya organisasi (X) terhadap variabel kompetensi. 
b. Uji korelasi antar indikator variabel: akan diketahui indikator mana yang paling kuat dan lemah kontribusinya terhadap masing-masing variabel.

c. Uji korelasi antar butir pertanyaan pada indikator: akan diketahui butir mana sajakah yang paling kuat dan lemah terhadap masing-masing indikator.

d. Dari hasil analisis data asosiatif akan diketahui kekuatan dan kelemahan pada masing-masing indikator vaiabel dan butir pertanyaan indikator, sehingga dapat digunakan sebagai bahan masukan dan perbaikan bagi perpustakaan maupun pustakawan di masa yang akan datang.

\section{Hasil Dan Pembahasan}

\section{Temuan Penelitian}

Hasil penelitian yang dilakukan, mendeskripsikan dan menampilkan data dalam bentuk tabel distribusi frekuensi untuk semua variabel yaitu Budaya Organisasi dan Kompetensi Pustakawan. Berikut merupakan uraian analisis dan pembahasan penelitian.

Hasil penelitian dari penyebaran angket sebanyak 26 responden, mendeskripsikan pengaruh antara Budaya Organisasi terhadap Kompetensi Pustakawan UII diuraikan sebagai berikut.

a. Jenis Kelamin

Tabel 2 Jenis Kelamin Pustakawan UII

\begin{tabular}{clcc}
\hline No & Jenis Kelamin & Jumlah & Persentase (\%) \\
\hline $\mathbf{1}$ & Laki-laki & 16 & 61,54 \\
\hline $\mathbf{2}$ & Perempuan & 10 & 38,46 \\
\hline & Jumlah & 26 & 100 \\
\hline
\end{tabular}

Sumber: Data Primer 2016 N=22

Tabel 2 menunjukkan bahwa pustakawan UII yang menjadi responden dalam penelitian ini berjenis kelamin laki-laki sebesar 16 orang $(61,54 \%)$, perempuan sebesar 10 orang $(38,46 \%)$. 
b. Usia

Tabel 3 Usia Pustakawan UII

\begin{tabular}{cccc}
\hline No & Usia (tahun) & Jumlah & Persentase (\%) \\
\hline $\mathbf{1}$ & Kurang dari 30 & 0 & 0 \\
\hline $\mathbf{2}$ & $31-40$ & 2 & 7,69 \\
\hline $\mathbf{3}$ & $41-50$ & 11 & 42,31 \\
\hline $\mathbf{4}$ & Lebih dari 51 & 13 & 50,00 \\
\hline & Jumlah & 26 & 100 \\
\hline
\end{tabular}

Sumber: Data Primer 2016 N=22

Tabel 3 menunjukkan bahwa pustakawan UII yang menjadi responden dalam penelitian ini sebagian besar berusia lebih 51 tahun sebanyak 13 orang (50\%), usia 41-50 tahun sebesar 11 orang (42,31\%), berusia antara 31-40 tahun sebesar 2 orang (7,69\%) dan berusia kurang dari 30 tahun sebanyak 0. Dari tabel 4.1.2 ini yang perlu mendapatkan perhatian oleh para pimpinan UII adalah bahwa pustakawan UII saat ini yang telah berusia 55 tahun ke atas ada sejumlah 6 orang, artinya dua sampai tiga tahun ke depan pustakawan UII akan berkurang 6 orang. Dan apabila dilihat untuk 7 tahun mendatang, maka pustakawan UII akan berkurang lagi 11 orang.

c. Pendidikan Terakhir

Tabel 4 Pendidikan Terakhir Pustakawan UII

\begin{tabular}{|c|c|c|c|}
\hline No & Tingkat Pendidikan & Jumlah & Persentase (\%) \\
\hline 1 & SLTA & 7 & 26,92 \\
\hline 2 & Diploma & 11 & 42,31 \\
\hline 3 & S1 & 3 & 11,54 \\
\hline 4 & S2 & 5 & 19,23 \\
\hline \multicolumn{2}{|r|}{ Jumlah } & 26 & 100 \\
\hline
\end{tabular}

Sumber: Data Primer 2016 N=22 
Dari tabel 4 tampak bahwa pendiddikan terakhir Pustakawan UII Diploma 11 orang (42,31\%), SLTA 7 orang (26,92\%), S2 5 orang (19,23\%) dan S1 3 orang (11,54\%). Dari data ini apabila mengacu pada Standar Nasional Perpustakaan Perguruan Tinggi, maka dapat tafsirkan bahwa sebesar 69,23\% terkelompok pada teknis perpustakaan (bukan berstatus sebagai pustakawan) dan hanya 30,77\% berstatus pustakawan murni. Dan apabila mengacu pada Permenpan Nomor 9 tahun 2014, bahwa saat ini pustakawan UII terdiri dari: pustakawan tingkat terampil sebanyak 69,23\% dan pustakawan tingkat ahli sebanyak 30,77\%.

d. Masa Kerja

Tabel 5 Masa Kerja Pustakawan UII

\begin{tabular}{clcc}
\hline No & Masa Kerja (tahun) & Jumlah & Persentase (\%) \\
\hline 1 & $<5$ & 0 & 0 \\
\hline 2 & $5-10$ & 0 & 0 \\
\hline 3 & $11-15$ & 2 & 7,69 \\
\hline 4 & $16-20$ & 4 & 15,38 \\
\hline 5 & $>21$ & 20 & 76,92 \\
\hline & Jumlah & 26 & 100 \\
\hline
\end{tabular}

Sumber: Data Primer 2016 N=22

Pada tabel 5 tampak bahwa masa kerja pustakawan UII sebanyak 20 orang $(79.92 \%)$ telah bekerja selama lebih dari 21 tahun, dan masa kerja antara 16-20 tahun sebesar 4 orang (15,38\%), dan lama bekerja antara 11-15 tahun sebanyak 2 orang (7,69\%). Sementara pustakawan yang memiliki masa kerja setara dengan 10 tahun atau kurang dari itu sejumlah 0 orang. 
e. Persepsi Responden terhadap Variabel Budaya Organisasi (X)

Tabel 6 Tingkat Persepsi Responden terhadap Variabel Budaya Organisasi

\begin{tabular}{|c|c|c|c|c|c|c|c|}
\hline \multirow{2}{*}{$\begin{array}{c}\text { Nama Indikator/ } \\
\text { Variabel }\end{array}$} & \multirow{2}{*}{$\begin{array}{c}\Sigma \text { Skor } \\
\text { Jawab } \\
\text { Resp }\end{array}$} & \multicolumn{3}{|c|}{$\begin{array}{l}\text { Skor Total }(78 \times \\
5 \times \Sigma \text { Kuis) } \\
\end{array}$} & \multirow{2}{*}{$\begin{array}{l}\text { Skor } \\
\text { Total }\end{array}$} & \multirow{2}{*}{$\begin{array}{l}\text { Hasil ( } \Sigma \text { skor } \\
\text { jawab resp: } \Sigma \text { skor } \\
\text { total x 100) }\end{array}$} & \multirow[t]{2}{*}{ Kategori } \\
\hline & & $26^{*}$ & $5^{* *}$ & $\sum$ Kuis & & & \\
\hline $\begin{array}{l}\text { Kreatif dan Mampu } \\
\text { Berspekulasi }\end{array}$ & 840 & 26 & 5 & 8 & 1040 & 80.8 & Sangat Tinggi \\
\hline Peduli Terhadap Profesi & 622 & 26 & 5 & 6 & 780 & 79,7 & Tinggi \\
\hline Fokus Terhadap Prestasi & 868 & 26 & 5 & 8 & 1040 & 83,5 & Sangat Tinggi \\
\hline Fokus Kepada Personal & 853 & 26 & 5 & 8 & 1040 & 82 & Sangat Tinggi \\
\hline $\begin{array}{l}\text { Fokus Kepada Satuan } \\
\text { Kerja/Kelompok }\end{array}$ & 1051 & 26 & 5 & 10 & 1300 & 80.8 & Sangat Tinggi \\
\hline Sifat Agresif & 761 & 26 & 5 & 7 & 910 & 83,6 & Sangat Tinggi \\
\hline $\begin{array}{l}\text { Kemantapan/ } \\
\text { Kenyamanan }\end{array}$ & 213 & 26 & 5 & 2 & 260 & 81,92 & Sangat Tinggi \\
\hline Budaya Organisasi & 5208 & 26 & 5 & 49 & 6370 & 81,76 & Sangat Tinggi \\
\hline
\end{tabular}

Sumber: data primer diolah $\mathrm{N}=26,2018$

Catatan: ${ }^{*}$ Jumlah Responden, ${ }^{* *}$ skor jawaban tertinggi pada butir pertanyaan

Variabel budaya organisasi terdiri atas 7 indikator, diantaranya adalah kreatif dan mampu berspekulasi, peduli terhadap profesi, fokus terhadap prestasi, fokus kepada personal, fokus kepada satuan kerja/kelompok, sifat agresif, dan kemantapan/ kenyamanan. Kuis/pertanyaan yang diajukan terhadap responden pada variabel budaya organisasi ini terdiri dari 52 butir pertanyaan, akan tetapi setelah dilakukan uji validitas terbukti 3 butir pertanyaan tidak valid (butir 7, 9 dan 50), sehingga hanya 49 butir yang dapat digunakan untuk melakukan uji statistik. Oleh responden diberikan persepsi sebagaimana disajikan pada Tabel 6.

Pada Tabel 6 tampak bahwa tingkatan di masing-masing indikator adalah indikator kreatif dan mampu berspekulasi dalam kategori sangat tinggi (80.8), peduli terhadap profesi dalam kategori tinggi $(79,7)$, fokus terhadap prestasi dalam kategori sangat tinggi (83.5), fokus kepada personal dalam kategori sangat tinggi (82), fokus kepada satuan kerja/ kelompok dalam kategori sangat tinggi (80.8), sifat agresif dalam kategori 
sangat tinggi $(83,6)$, dan kemantapan/ kenyamanan dalam kategori tinggi $(81,92)$. Sementara persepsi responden terhadap variabel budaya organisasi dalam kategori sangat tinggi dengan skor nilai 81,76.

Budaya organisasi mempengaruhi kinerja dan produktivitas organisasi dengan cara yang luar biasa. Hal ini disetujui oleh Shuaib Ahmed $\mathrm{dkk}^{19}$ yang menyatakan bahwa budaya organisasi berdampak pada kemajuan karir karyawan, ia memainkan peran penting dalam membentuk kemajuan karir karyawan. Hasil signifikan pada tingkat 0.05\% dari perspektif budaya organisasi dan perspektif pengembangan karir karyawan. Organisasi yang tidak mempromosikan prakarsa kewirausahaan dan pengambilan risiko, kurang memotivasi karyawan, membuat mereka enggan dan akibatnya mempengaruhi kinerja organisasi dan pengembangan karir karyawan. Lebih lanjut Shuaib Ahmed dkk menjelaskan bahwa suatu oraganisasi perlu memberikan kerangka kerja dan pentingnya budaya organisasi yang berguna bagi para pegawainya.

Perkembangan karir karyawan dapat diuntungkan melalui kebebasan pegawai (dalam hal ini pustakawan) untuk mengembangkan diri yang meliputi kreatif dan mampu berspekulasi dalam menghadapi berbagai ujian dan tantangan, kepedulian terhadap profesi, memiliki visi dan misi terhadap prestasi, fokus kepada personal, fokus kepada satuan kerja/kelompok, sifat agresif dan keinginan untuk maju, dan adanya kemantapan/kenyamanan dalam melaksanakan tugas-tugasnya.

Dari olah data, dalam penelitian ini ditemukan bahwa aspek kemantapan/kenyamanan dalam bekerja bagi pustakawan menduduki urutan paling rendah. Suasana kerja yang nyaman dan rasa mantap dalam menjalani pekerjaan merupakan kunci sukses dalam meniti karir. Meskipun indikator kemantapan dan kenyamanan menduduki urutan paling rendah, akan tetapi secara umum variabel budaya organisasi di Perputakaan UII dipersepsikan oleh responden dalam tingkatan kategori

${ }^{19}$ Shuaib Ahmed dkk. 2014. Organizational Culture and its Impact on Employee Career Progression in Public Sector Organizations in Pakistan. IBT Journal of Business Studies (Formerly Journal of Management \& Social Sciences) Vol. 10, No. 2, (Fall 2014) 56-70 
sangat tinggi. Berarti bahwa di Perpustakaan UII telah memiliki dan meletakkan budaya organisasi sebagai kebijakan yang telah diambil secara organisatoris. Bahwa nilai-nilai, tatakrama kerja, etika, kebiasaan kerja yang baik telah dikembangkan dan diterima oleh para pustakawan.

f. Persepsi Responden terhadap Variabel Kompetensi (Y)

Variabel kompetensi terdiri atas 6 indikator, diantaranya adalah knowledge, pemahaman, kemampuan, nilai/value, sikap, dan minat. Kuis/pertanyaan yang diajukan terhadap responden pada variabel kompetensi ini terdiri dari 17 butir pertanyaan, dan setelah dilakukan uji validitas terbukti seluruh butir pertanyaan dinyatakan valid, sehingga 17 butir pertanyaan dapat digunakan untuk melakukan uji statistik. Oleh responden diberikan persepsi sebagaimana disajikan pada Tabel 7

Tabel 7 Tingkat Persepsi Responden terhadap Variabel Kompetensi

\begin{tabular}{|c|c|c|c|c|c|c|c|}
\hline \multirow{2}{*}{$\begin{array}{c}\text { Nama } \\
\text { Indikator/ } \\
\text { Variabel }\end{array}$} & \multirow{2}{*}{$\begin{array}{c}\Sigma \text { Skor } \\
\text { Jwb Resp }\end{array}$} & \multicolumn{3}{|c|}{$\begin{array}{c}\text { Skor Total }(78 \times 5 \times \\
\Sigma \text { Kuis })\end{array}$} & \multirow{2}{*}{$\begin{array}{l}\text { Skor } \\
\text { Total }\end{array}$} & \multirow{2}{*}{$\begin{array}{c}\text { Hasil }(\Sigma \text { skor jawab } \\
\text { resp: } \Sigma \text { skor total } x \\
100)\end{array}$} & \multirow[t]{2}{*}{ Kategori } \\
\hline & & $26^{*}$ & $5^{* *}$ & $\sum$ Kuis & & & \\
\hline Knowledge & 322 & 26 & 5 & 3 & 390 & 82.6 & Sangat Tingg \\
\hline Pemahaman & 217 & 26 & 5 & 2 & 260 & 83.5 & Sangat Tingg \\
\hline Kemampuan & 451 & 26 & 5 & 4 & 520 & 86.7 & Sangat Tingg \\
\hline Nilai & 213 & 26 & 5 & 2 & 260 & 81.9 & Sangat Tingg \\
\hline Sikap & 318 & 26 & 5 & 3 & 390 & 81.5 & Sangat Tingg \\
\hline Minat & 341 & 26 & 5 & 3 & 390 & 87,4 & Sangat Tingg \\
\hline Kompetensi & 1862 & 26 & 5 & 17 & 2210 & 84.25 & Sangat Tingg \\
\hline
\end{tabular}

Sumber: data primer diolah $\mathrm{N}=26,2018$

Catatan: ${ }^{\star} J u m l a h$ Responden, ${ }^{\star *}$ skor jawaban tertinggi pada butir pertanyaan

Pada Tabel 7 tampak bahwa tingkatan di masing-masing indikator dan variabel kompetensi dalam kategori sangat tinggi. Dari 6 indikator yang memiliki urutan kategori sangat tinggi skor tertinggi adalah indikator minat dengan skor 87,4 , disusul berturut-turut indikator kemampuan sebesar 86.7, indikator pemahaman sebesar 83,5, indikator knowledge sebesar 82.6, indikator nilai sebesar 81.9, dan indikator sikap dengan skor sebesar 81,5. 
Sementara kategori variabel kompetensi oleh responden dipersepsikan dalam kategori sangat tinggi dengan skor 84,25.

Atas dasar hasil olah data di atas terbukti bahwa pustakawan UII Yogyakarta telah memiliki kompetensi yang sangat tinggi. Ini merupakan modal besar baginya dalam rangka meraih kematangan karir sebagai pustakawan. Kompetensi yang diharapkan adalah sesuai dengan ajaran Agama Islam, sebagaimana yang terdapat dalam Al Quran dan Hadis Nabi Muhammad SWT. Ayat-ayat Quran yang dapat diguanakan antara lain, QS Al Baqarah 267, Ali Imran 191, dan Al Ma’idah ayat 2, (lihat lampiran terjemah Quran nomor 1).

Inti dari QS 2:267 tersebut adalah bahwa pustakawan perlu memiliki komitmen memberikan layanan terbaik sesuai dengan potensi yang dimilikinya.

Pada Quran Ali Imran ayat 191 ini pustakawan dituntut untuk berpikir secara mendalam antara lain meliputi pemikiran luas dan dalam, memiliki perasaan dan hati halus serta kepekaan, daya pikir kritis, pandangan luas dan dalam, pengetahuan, kebijaksanaan (wisdom) yaitu mampu mendekati kebenaran dengan pertimbangan adil dan terbuka.

Sementara pada Ayat 2 Quran Al Ma'idah tersebut memberikan arahan bagi pustakawan bahwa, dalam menjalankan kompetensinya diperlukan kemampuan untuk menjalin kerja sama dengan kawan, pimpinan, lembaga induk dimana mereka bekerja, organisasi profesi, dan lain-lain.

\section{Uji Validitas dan Reliabilitas Instrumen Penelitian}

Riset ini menggunakan angket sebagai alat untuk menguji apakah kuesioner penelitian yang digunakan valid atau tidak. Azwar menjelaskan bahwa validitas merupakan sarana untuk menguji sejauh mana ketepatan dan kecermatan suatu instrumen dalam menjalankan perannya sebagai alat ukur penelitian ${ }^{20}$.

${ }^{20}$ Saifuddin Azwar. 2003. Reliabilitas dan Validitas. (Yogyakarta: Pustaka Pelajar). hal. 5 
Uji validitas pada riset ini dibantu oleh program SPSS dengan menggunakan analisis regresi ganda dan analisis jalur. Analisis regresi berganda digunakan untuk mengetahui pengaruh antar dua variabel atau lebih, sementara analisis jalur dimaksudkan untuk mengetahui pengaruh langsung maupun tidak langsung antara variabel bebas dengan variabel terikat dengan melalui variabel intervening.

Analisis ini dihitung dengan cara mengkorelasikan pada setiap skor pertanyaan (masing-masing variabel) dengan skor total variabel. Skor total variabel adalah penghitungan dari keseluruhan butir pertanyaan (variabel). Butir-butir pernyataan yang berkorelasi substansial dengan jumlah total membuktikan butir-butir tersebut berkontribusi terhadap apa yang ingin diketahui.

Pengujian dengan menerapkan taraf signifikansi 5\% $(\alpha=0,05)$. Kriteria pengujiannya adalah sebagai berikut:

a. Apabila $\mathrm{r}_{\text {hitung }} \geq \mathrm{r}_{\text {tabel }}$ (signifikansi 0,05) maka butir-butir pertanyaan berpengaruh signifikan terhadap jumlah total (berarti valid).

b. Apabila $\mathrm{r}_{\text {hitung }}<\mathrm{r}_{\text {tabel }}$ (signifikansi 0,05) maka butir-butir pertanyaan tidak berpengaruh signifikan terhadap jumlah total (berarti tidak valid).

Sementara uji reliabilitas data berfungsi untuk menilai instrumen sebagai tolok ukur terhadap konstruk penelitian. Instrumen dinyatakan reliabel atau handal apabila jawaban responden terhadap pertanyaan selalu ajeg dan konsisten dari masa ke masa. Reliabilitas yang memiliki keajegan jawaban apabila digunakan secara berulang-ulang pada sampel yang berbeda. Aplikasi SPSS dapat membantu menguji kehandalan instrumen penelitian dengan uji statistik Croncbach's Alpha. ${ }^{21}$

Dalam penelitian ini menggunakan Croncbach's Alpha untuk mengukur konsistensi internal instrumen. Menurut Sekaran klasifikasi nilai Cronbach's Alpha, sebagai berikut ${ }^{22}$ :

${ }^{21}$ Imam Ghozali. 2006.Aplikai Analisis Multivarite dengan SPSS, Cetakan Keempat. (Semarang: Badan Penerbit Universitas Diponegoro), hlm. 41-42.

${ }_{22}$ Uma Sekaran. 2003. Research Methods for Business; A Skill Building Approach, 4th Ed. (New York: John Wiley \& Sons Inc), hlm. 307-314. 
a. Skor Cronbach's Alpha antara 0,80 - 1,0 diklasifikasikan kehandalan baik.

b. Skor Cronbach's Alpha antara 0,60 - 0,79 diklasifikasikan kehandalan dapat diterima.

c. Nilai Cronbach's Alpha $\leq$ 0,60 diklasifikasikan kehandalan buruk.

Seperti yang direncanakan untuk melakukan uji validitas dan kehandalan instrumen penelitian dilakukan uji Korelasi Product Product Moment dengan menggunakan software SPSS 16.0. Dengan uji konfirmatori akan dapat diketahui apakah indikator-indikator variabel penelitian benarbenar dapat mengkonfirmasi atau mencerminkan nilai dari sebuah kinstruk yang sedang dibangun dalam studi ini.

Untuk mengetahui tingkat reliabilitas instrumen penelitian, maka dapat dilihat dari hasil output hitungan, jika diketahui bahwa nilai $r_{\text {hitung }}$ Alpha lebih besar dari 0.6 dimana dalam ketentuan menyebutkan bahwa apabila harga $r_{\text {hitung }}$ melebihi angka 0,6, maka kuisioner dalam penelitian itu dinyatakan handal.

Sementara untuk mengetahui tingkat validitas instrumen penelitian maka jika dari hasil hitungan correlations $\mathrm{r}_{\text {hitung }}$ lebih besar dari nilai kritis $\left(r_{\text {tabel }}\right)$ maka instrumen itu dinyatakan valid. Pada studi ini dimana nilai $r_{\text {tabel }}$ untuk $\mathrm{N}=26$ dengan tingkat kesalahan 5\% adalah 0.220 dan 0.286 untuk tingkat kesalahan $1 \%$.

Tabel 8 Hasil Uji Reliabilitas Instrumen Variabel

\begin{tabular}{clcc}
\hline No & Variabel Penelitian` & Nilai Cronbach's & Keterangan \\
\hline 1. & Budaya Organisasi (X) & 0.945 & Kehandalan Baik \\
\hline 2. & Kompetensi $(\mathrm{Y})$ & 0.925 & Kehandalan Baik \\
\hline
\end{tabular}

Sumber: data primer diolah $\mathrm{N}=26,2018$

\section{a. Uji Validitas dan Reliabilitas Variabel Budaya Organisasi}

Variabel budaya organisasi dalam penelitian ini diberikan simbol $\mathrm{X}$ dengan pengukuran sebanyak 7 indikator, yang meliputi $\mathrm{X}_{1}$ kreatif dan mampu berspekulasi; $\mathrm{X}_{2}$ peduli terhadap profesi; $\mathrm{X}_{3}$ fokus terhadap prestasi; 
$\mathrm{X}_{4}$ fokus kepada personal; $\mathrm{X}_{5}$ Fokus kepada satuan kerja/kelompok; $\mathrm{X}_{6}$ sifat agresif; dan $\mathrm{X}_{7}$ kemantapan/kenyamanan. Dari hasil perhitungan dapat diketahui bahwa nilai Alpha sebesar 0,945 lebih besar dari 0.6 dimana dalam ketentuan menyebutkan bahwa apabila harga $\mathrm{r}_{\text {hitung }}$ lebih besar dari 0,6, maka kuisioner dalam penelitian itu dinyatakan reliabel. Kesimpulannya nilai hitung $($ Alpha $)=0,945>0.6$ sehingga item-item pertanyaan pada angket ini dapat dikatakan reliabel atau terpercaya sebagai alat pengumpul data dalam penelitian.

Sementara untuk mengetahui tingkat validitas instrumen penelitian maka dari hasil hitungan correlations dapat diketahui bahwa dari 52 pertanyaan dalam kuisioner penelitian pada variabel budaya organisasi 49 pertanyaan memiliki nilai $r_{\text {hitung }}$ 0,729. Angka ini lebih besar dari $r_{\text {tabel }}$. Dimana nilai $\mathrm{r}_{\text {tabel }}$ untuk $\mathrm{N}=26$ adalah 0.374 dengan tingkat kesalahan $5 \%$, sehingga 49 butir pertanyaan dinyatakan valid dan 3 pertanyaan tidak valid (butir 7 , 9 dan 50) dengan nilai $\mathrm{r}_{\text {hitung }} 0.119,0.213$, dan 0.126.

Dari hasil hitungan tersebut, maka dapat dinyatakan bahwa angkaangka hasil perhitungan memenuhi kriteria yang disyaratkan, sehingga dapat dinyatakan instrumen penelitian yang mengukur indikator-indikator variabel budaya organisasi adalah valid dan reliabel. Dengan demikian indikatorindikator variabel budaya organisasi $\left(\mathrm{X}_{2}\right)$ layak untuk menguji hipotesis yang diajukan dalam penelitian ini, kecuali pertanyaan butir 7, 9 dan 50 .

\section{b. Uji Validitas dan Reliabilitas Variabel Kompetensi}

Variabel kompetensi dalam penelitian ini diberikan simbol Y dengan pengukuran sebanyak 6 indikator, yang meliputi $\mathrm{Y}_{1}$ knowledge; $\mathrm{Y}_{2}$ pemahaman; $\mathrm{Y}_{3}$ kemampuan; $\mathrm{Y}_{4}$ value; $\mathrm{Y}_{5}$ sikap; dan $\mathrm{Y}_{6}$ minat. Dari hasil perhitungan dapat diketahui bahwa nilai Alpha sebesar 0,925 lebih besar dari 0.6 dimana dalam ketentuan menyebutkan bahwa apabila harga $r_{\text {hitung }}$ lebih besar dari 0,6, maka kuisioner dalam penelitian itu dinyatakan reliabel. Kesimpulannya nilai hitung (Alpha) $=0,925>0.6$ sehingga item-item pertanyaan pada angket ini dapat dikatakan reliabel atau terpercaya sebagai alat pengumpul data dalam penelitian. 
Sementara untuk mengetahui tingkat validitas instrumen penelitian maka dari hasil hitungan correlations dapat diketahui bahwa dari 17 pertanyaan dalam kuisioner penelitian pada variabel kompetensi 17 pertanyaan memiliki nilai $r_{\text {hitung }}$ 0,752. Angka ini lebih besar dari $r_{\text {tabel }}$. Dimana nilai $r_{\text {tabel }}$ untuk $\mathrm{N}=26$ adalah 0.374 dengan tingkat kesalahan 5\%, sehingga 17 butir pertanyaan dinyatakan valid.

Dari hasil hitungan tersebut, maka dapat dinyatakan bahwa angkaangka hasil perhitungan memenuhi kriteria yang disyaratkan, sehingga dapat dinyatakan instrumen penelitian yang mengukur indikator-indikator variabel kompetensi adalah valid dan reliabel. Dengan demikian indikator-indikator variabel kompetensi (Y) layak untuk menguji hipotesis yang diajukan dalam penelitian ini.

\section{Uji Korelasi}

Korelasi selain dapat untuk mengetahui derajat/keeratan hubungan, dapat juga untuk mengetahui arah hubungan dua variabel numerik. Dalam penelitian ini akan dicari hubungan antara kepercayaan diri pustakawan UII dengan pengembangan karir pustakawan UII.

Tabel 9. Hasil Uji Korelasi Budaya Organisasi terhadap Kompetensi

\section{Correlations}

\begin{tabular}{|c|c|c|c|}
\hline & & $\begin{array}{c}\text { Budaya } \\
\text { Organisasi }\end{array}$ & Kompetensi \\
\hline \multirow{3}{*}{$\begin{array}{l}\text { Budaya } \\
\text { Organisasi }\end{array}$} & Pearson Correlation & 1 & $.478^{*}$ \\
\hline & Sig. (2-tailed) & & .014 \\
\hline & $\mathrm{N}$ & 26 & 26 \\
\hline \multirow[t]{3}{*}{ Kompetensi } & Pearson Correlation & $.478^{*}$ & 1 \\
\hline & Sig. (2-tailed) & .014 & \\
\hline & $\mathrm{N}$ & 26 & 26 \\
\hline
\end{tabular}

${ }^{\star}$ Correlation is significant at the 0.05 level (2-tailed). 
Dari hasil hitungan di atas diketahui bahwa terdapat pengaruh Budaya Organisasi Perpustakaan UII (X) terhadap Kompetensi Pustakawan UII (Y) dengan nilai signifikansi 0,014 < 0,05 $(0,014)$ lebih kecil dari 0,05). Sementara tingkat korelasi antara variabel $\mathrm{X}$ dengan variabel $\mathrm{Y}$ terdapat pengaruh sebesar 47,8\% (0,478) dimana kriteria tingkat pengaruh (koefisien korelasi antar variable berkisar antara +0.00 sampai $+1,00$ dengan rincian sebagai berikut:

Tabel 10 Kriteria Tingkat Pengaruh antar Variabel

\begin{tabular}{cll}
\hline No & \multicolumn{1}{c}{ Skor Korelasi } & \multicolumn{1}{c}{ Kategori Korelasi } \\
\hline 1 & $0,00-0,20$ & Hampir Tidak Ada Korelasi \\
2 & $0,21-0,40$ & Korelasi Rendah \\
3 & $0,41-0,60$ & Korelasi Sedang \\
4 & $0,61-0,80$ & Korelasi Tinggi \\
5 & $0,81-1,00$ & Artinya Korelasi Sempurna \\
\hline
\end{tabular}

Dari hasil peneltian ini diperoleh hasil bahwa tingkat korelasi antara budaya organisasi terhadap kompetensi pustakawan UII adalah sebesar 47,80\% (0,478). Artinya pengaruh kompetensi pustakawan UII dari budaya organisasi hanya sebesar $47,80 \%$ saja, sementara masih ada faktor diluar budaya organisasi sebesar 58,20\% yang mempengaruhi kompetensi pustakawan.

Berdasarkan hasil uji korelasi tersebut diatas dapat disimpulkan bahwa dalam penelitian ini menerima hipotesis yang menyatakan bahwa terdapat pengaruh antara budaya organisasi terhadap kompetensi pustakawan UII dalam menjalani profesinya. Sementara tingkat pengaruh budaya organisasi terhadap kompetensi pustakawan UII pada kategori sedang.

\section{Pembahasan}

Pengaruh Budaya Organisasi (X) terhadap Kompetensi (Y)

Pengaruh budaya organisasi (X) terhadap kompetensi (Y) dibuktikan dengan pernyataan bahwa persepsi pustakawan UII Yogyakarta mengenai 
budaya organisasi $(\mathrm{X})$ mempunyai pengaruh signifikan terhadap kompetensi dengan angka substansial $(0,014<0,05)$. Hasil kajian sudah dilaksanakan lewat analisis data secara simultan yang hasilnya ditampilkan pada Tabel 4.3 dan telah dijelaskan bahwa pengaruh langsung persepsi pustakawan UII Yogyakarta antara variabel budaya organisasi (X) terhadap variabel kompetensi (Y) senilai 0,478 dengan derajat substansial senilai 0,014. Hal ini membuktikan bahwa ada pengaruh yang positif dan substansial antara budaya organisasi $(\mathrm{X})$ terhadap kompetensi (Y). Hasil ini memiliki arti bahwa budaya organisasi yang dipersepsikan pada pustakawan merupakan fenomena yang positif (baik, tinggi), maka persepsi pustakawan terhadap kompetensi juga akan baik (tinggi).

Budaya organisasi yang merupakan norma-norma dominan, keyakinan-keyakinan, dan asumsi yang dikembangkan sejelan dengan waktu dan disepakati bersama oleh sebagian besar pustakawan dalam perpustakaan yang menentukan bagaimana pola perilaku dan kebiasaan kerja para pustakawan sehingga menjadi sejumlah kebijakan dan praktik manajemen. Empat sifat utama yang mengukur budaya organisasi adalah keterlibatan, konsistensi, adaptabilitas, dan penghayatan misi.

Hasil riset ini selaras dengan penelitian yang dilakukan oleh JeongSil Choi dan Ji-Soo Kim bahwa, kompetensi budaya siswa meningkat saat pengalaman budaya ditambahkan ke pendidikan budaya. Antara pengalaman budaya, kontak dengan orang-orang dari daerah budaya lainnya mempengaruhi kompetensi budaya siswa keperawatan. Oleh karena itu, dianjurkan untuk mendorong siswa keperawatan untuk terlibat dalam ekstrakurikuler kegiatan dengan orang-orang dari negara lain, dan menambahkan kegiatan ini ke ceramah terorganisir mengenai pendidikan budaya. Sejalan dengan tren globalisasi, setiap negara menjadi lebih multikultural Menanggapi diversifikasi budaya pasien, program pendidikan budaya yang sistematis dan lebih efektif diperlukan untuk memberikan perawatan yang sesuai secara budaya. Namun, studi terbaru telah melaporkan bahwa siswa keperawatan menganggap mereka tidak siap memberikan pelayanan budaya yang kompeten, walaupun pendidikan budaya disediakan 
dalam kurikulum keperawatan mereka. Dengan demikian, penelitian ini mencari strategi efektif yang dapat meningkatkan kompetensi budaya keperawatan siswa. Hasil penelitian menunjukkan bahwa kekuatan penjelasan pengalaman pribadi dengan budaya lain serupa dengan pendidikan budaya. Kompetensi budaya keperawatan ditingkatkan secara personal pengalaman sebanyak penawaran kurikulum reguler budaya pendidikan. Dengan demikian, solusi pendidikan jangka panjang harus mencakup kegiatan ekstrakurikuler yang memungkinkan siswa untuk mendalami berbagai budaya. Hal ini dapat meningkatkan kompetensi budaya siswa. Pelajaran ini memberikan wawasan baru tentang peningkatan kompetensi budaya secara efektif menggunakan alat pendidikan budaya saat ini dalam kurikulum pendidikan.

Hasil studi yang dilakukan oleh Zangiski, de Lima, dan da Costa juga menguatkan temuan pada peneletian ini yang terkait dengan pengaruh budaya organisasi terhadap kompetensi. Pembelajaran organisasional muncul sebagai hasil dari proses interaktif, dan memahami hubungan antar personal di dalam organisasi, berbagi informasi, eksperimen, dan penyebaran pengetahuan, di antara unsur-unsur lain yang melekat pada proses interaksi organisasi, terutama dalam konteks manajemen operasi/operations management (OM). Relevansi kompetensi organisasi untuk mobilisasi sumber daya dan pemenuhan tujuan strategis organisasi adalah akal sehat di antara penulis yang terbiasa menyusun basis teoritis. Selain itu, manajemen kompetensi semacam itu menuntut pemahaman dasar mengenai budaya organisasi, tampilan sistemik, dan khususnya, proses pembelajaran organisasi. Studi ini memungkinkan identifikasi dan pembentukan interkoneksi proses yang terjadi, serta antarmuka di antara elemen-elemen, arti pentingnya pembelajaran organisasi dan praktik dengan pengembangan kompetensi. Dalam pengertian ini, hasil riset berperan pada pengetahuan yang lebih baik terhadap peran proses pembelajaran institusi dan hubungannya dengan pembentukan dan pengembangan kompetensi, terutama mengenai nilai sebagai pengetahuan yang berlaku. Proses semacam itu dipahami di tingkat operasi dengan menghubungkan berbagai area dan fungsi dalam organisasi. 
Dengan pemikiran ini, penelitian ini berkontribusi terhadap area OM, karena penerapkan teori dan model pembelajaran organisasi dan kompetensi, dan mengevaluasi elemen yang terlibat dan keterkaitan dan antarmuka mereka dalam pendekatan berbasis OM.

\subsection{Kekuatan Indikator Variabel Budaya Organisasi (X)}

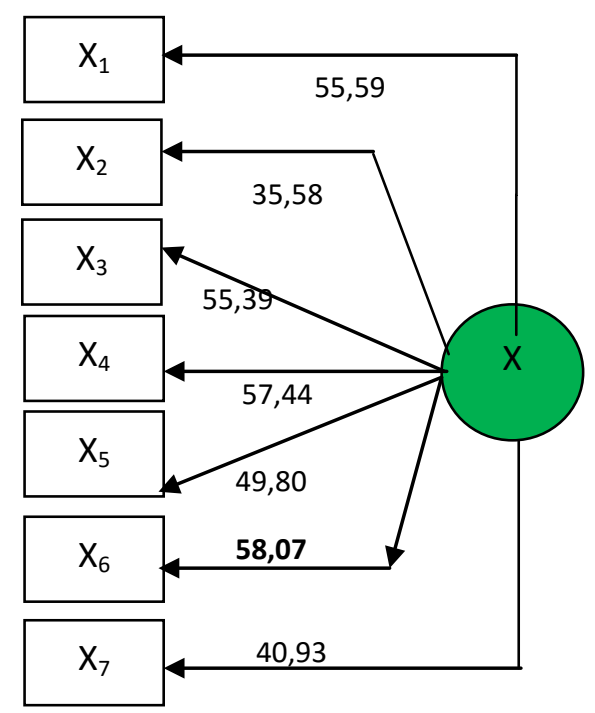

Gambar 1 Kekuatan Indikator terhadap Variabel Budaya Organisasi

Variabel budaya organisasi (X) memiliki 7 indikator yakni (kreatif dan mampu berspekulasi, peduli terhadap profesi, fokus terhadap prestasi, fokus kepada personal, fokus kepada satuan kerja/kelompok, sifat agresif, dan kemantapan) masing-masing memiliki kekuatan: 55,59\%; 35,58\%; 55,39\%; 57,44\%; 49,80\%; 58,07\% dan 40,93\%. Kekuatan terbesar terletak pada indikator sifat agresif $(58,07 \%)$ dan terkecil pada aspek peduli terhadap profesi $(35,58)$. 
Tabel 11 Kekuatan Indikator X terhadap Variabel Budaya Organisasi (X) One-Sample Test

\begin{tabular}{|c|c|c|c|c|c|c|}
\hline \multirow{3}{*}{$\begin{array}{c}\text { Skor Indikator Variabel } \\
\text { Budaya Organisasi }\end{array}$} & \multicolumn{6}{|c|}{ Test Value $=0$} \\
\hline & \multirow[b]{2}{*}{$\mathrm{t}$} & \multirow[b]{2}{*}{ df } & \multirow{2}{*}{$\begin{array}{c}\text { Sig. } \\
\text { (2-tailed) }\end{array}$} & \multirow{2}{*}{$\begin{array}{c}\text { Mean } \\
\text { Difference }\end{array}$} & \multicolumn{2}{|c|}{$\begin{array}{c}95 \% \text { Confidence Interva } \\
\text { of the Difference }\end{array}$} \\
\hline & & & & & Lower & Upper \\
\hline X.1 Kreatif & 55.591 & 25 & .000 & 32.308 & 31.11 & 33.50 \\
\hline X.2 Peduli terhadap Profesi & 35.581 & 25 & .000 & 23.923 & 22.54 & 25.31 \\
\hline X.3 Fokus kepada Prestasi & 55.387 & 25 & .000 & 33.385 & 32.14 & 34.63 \\
\hline X.4 Fokus kepada Personal & 57.441 & 25 & .000 & 32.808 & 31.63 & 33.98 \\
\hline X.5 Fokus kepada Tim & 49.795 & 25 & .000 & 40.423 & 38.75 & 42.09 \\
\hline X.6 Keagresifan & 58.073 & 25 & .000 & 29.269 & 28.23 & 30.31 \\
\hline X.7 Kemantapan & 40.931 & 25 & .000 & 8.192 & 7.78 & 8.60 \\
\hline
\end{tabular}

Sumber: data primer diolah $\mathrm{N}=26,2018$

Sementara itu dari indikator sifat agresif tersebut terdiri dari 7 butir pernyataan, setelah dilakukan perhitungan dapat diketahui hasilnya bahwa, dari indikator sifat agresif ini memiliki 5 kekuatan aspek terbesar antara lain meliputi: seorang pustakawan dalam melaksanakan tugas penuh dengan tanggung jawab (75,22\%), bekerja sesuai SOP yang ada (56,26\%), berperilaku sesuai dengan aturan dan norma yang ada $(64,16 \%)$, senang berbagi pengetahuan $(81,24 \%)$, dan selalu giat bekerja meskipun tidak ada yang mengawasi $(71,61 \%)$.

Tabel 12 Kekuatan "Butir Pernyataan/Pertanyaan” terhadap Indikator Sifat Agresif

\begin{tabular}{|c|c|c|c|c|c|c|}
\hline \multirow{3}{*}{$\begin{array}{c}\text { Skor Butir } \\
\text { Pernyataan } \\
\text { Indikator Sifat } \\
\text { Agresif }\end{array}$} & \multicolumn{6}{|c|}{ Test Value $=0$} \\
\hline & \multirow[t]{2}{*}{$\mathrm{t}$} & \multirow[t]{2}{*}{$\mathrm{df}$} & \multirow{2}{*}{$\begin{array}{c}\text { Sig. } \\
\text { (2-tailed) }\end{array}$} & \multirow{2}{*}{$\begin{array}{c}\text { Mean } \\
\text { Difference }\end{array}$} & \multicolumn{2}{|c|}{$\begin{array}{l}\text { 95\% Confidence Interval of } \\
\text { the Difference }\end{array}$} \\
\hline & & & & & Lower & Upper \\
\hline Agresif-43 & 75.22 & 25 & .000 & 4.269 & 4.16 & 4.38 \\
\hline Agresif-44 & 48.35 & 25 & .000 & 3.923 & 3.76 & 4.08 \\
\hline Agresif-45 & 56.26 & 25 & .000 & 4.077 & 3.93 & 4.22 \\
\hline Agresif-46 & 64.16 & 25 & .000 & 4.179 & 4.05 & 4.31 \\
\hline Agresif-47 & 81.24 & 25 & .000 & 4.321 & 4.21 & 4.43 \\
\hline Agresif-48 & 71.61 & 25 & .000 & 4.269 & 4.15 & 4.39 \\
\hline Agresif-49 & 52.96 & 25 & .000 & 3.679 & 3.54 & 3.82 \\
\hline
\end{tabular}

Sumber: data primer diolah $\mathrm{N}=26,2018$ 
Dari hasil kajian ini dapat disimpulkan bahwa kompetensi pustakawan UII Yogyakarta dipengaruhi oleh aspek sifat agresif, yang berarti bahwa seorang pustakawan didalam menjalankan profesinya perlu penuh tanggung jawab, bekerja sesuai dengan prosedur, berperilaku sesuai dengan aturan dan norma, tidak pelit terhadap ilmu yang dimiliki, dan giat bekerja walaupun tidak sedang diawasi.

\subsection{Kekuatan Indikator Variabel Kompetensi (Y)}

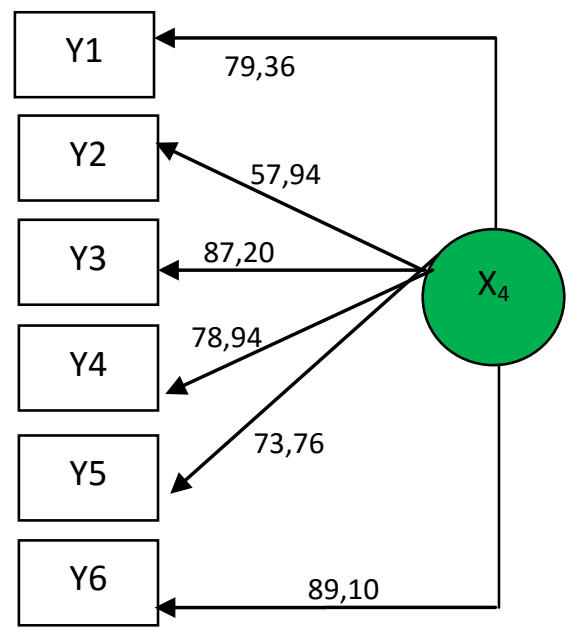

Gambar 2 Kekuatan Indikator terhadap Variabel Kompetensi

Variabel kompetensi (Y) memiliki 6 indikator (knowledge, pemahaman, kemampuan, nilai, sikap, dan minat) masing-masing memiliki kekuatan: 79,36\%; 57,94\%; 87,20\%; 78,94\%; 73,76 dan 89,10\%. Kekuatan terbesar terletak pada indikator minat $(89,10 \%)$ dan terkecil pada aspek pemahaman $(57,94 \%)$.

Sementara itu dari indikator skill dan interest tersebut terdiri dari 7 butir pernyataan/pertanyaan, setelah dilakukan perhitungan dapat diketahui hasilnya bahwa, seorang pustakawan dalam melaksanakan tugas perlu memiliki indikator skill dan interest yang memiliki 5 kekuatan aspek terbesar antara lain: mampu menjalin kerjasama (79,70\%), mampu ber- 
komunikasi dengan baik (67,58\%), bertanggung jawab (78,60\%), visioner dan berkeinginan untuk maju (75,35\%), dan mantap dalam menjalani profesi $(74,16 \%)$.

Tabel 13 Kekuatan Indikator Y terhadap Variabel Kompetensi (Y)

\begin{tabular}{|c|c|c|c|c|c|c|}
\hline \multirow{3}{*}{$\begin{array}{c}\text { Skor Indikator } \\
\text { Variabel } \\
\text { Kompetensi }\end{array}$} & \multicolumn{6}{|c|}{ Test Value $=0$} \\
\hline & \multirow[b]{2}{*}{$\mathrm{t}$} & \multirow[b]{2}{*}{$\mathrm{df}$} & \multirow{2}{*}{$\begin{array}{c}\text { Sig. } \\
\text { (2-tailed) }\end{array}$} & \multirow{2}{*}{$\begin{array}{c}\text { Mean } \\
\text { Difference }\end{array}$} & \multicolumn{2}{|c|}{$\begin{array}{l}\text { 95\% Confidence Interval of } \\
\text { the Difference }\end{array}$} \\
\hline & & & & & Lower & Upper \\
\hline Y.1 Knowledge & 79.36 & 25 & .000 & 12.115 & 11.81 & 12.42 \\
\hline Y.2 Pemahaman & 57.94 & 25 & .000 & 7.846 & 7.58 & 8.12 \\
\hline Y.3 Skill & 87.20 & 25 & .000 & 16.577 & 16.20 & 16.96 \\
\hline Y.4 Value & 78.94 & 25 & .000 & 8.064 & 7.86 & 8.27 \\
\hline Y.5 Sikap & 73.76 & 25 & .000 & 12.192 & 11.86 & 12.52 \\
\hline Y.6 Minat & 89.10 & 25 & .000 & 12.744 & 12.46 & 13.03 \\
\hline
\end{tabular}

Sumber: data primer diolah $\mathrm{N}=26,2018$

Modal dasar yang perlu dimiliki oleh pustakawan berupa skill dan interest ini perlu dipersiapkan sejak awal ketika mereka menjalani karir sebagai pustakawan. Hal ini selaras dengang apa yang dikemukakan oleh Sara Holder dan Amber Lannon (2018) ${ }^{23}$ yang menyatakan bahwa, pengalaman pustakawan di awal karier, dalam angkatan kerja saat ini, banyak (tetapi tidak semua) pustakawan di awal karier akan berasal dari generasi Milenium. Mengingat bahwa pertumbuhan pekerjaan perpustakaan lebih lambat dari yang diperkirakan, tantangan signifikan pertama bagi pustakawan baru adalah mengamankan posisi dengan modal utama berupa skill dan interest tersebut. Setelah dipekerjakan, ada peluang dan tantangan bagi pustakawan pemula. Ada banyak sumber dukungan dan sumber daya untuk dukungan tambahan. Utamanya bagi pustakawan akademik baru, tidak hanya ada tantangan untuk mempelajari pekerjaan baru mereka, tetapi juga untuk menavigasi masa jabatan dan proses promosi.

${ }^{23}$ Sara Holder \& Amber Lannon. 2018. Managing the Multigenerational Librarian Workforce. Elsevier Ltd. All rights reserved on line, hal 21-35. 
Dari hasil hitungan Tabel 14 dapat disimpulkan bahwa kekuatan dari masing-masing indikator pada variabel kompetensi Pustakawan UII Yogyakarta terletak pada aspek skill dan minat/interest yang tinggi, yang berarti bahwa seorang pustakawan didalam menjalankan profesinya harus mampu menjalin kerjasama, mampu berkomunikasi dengan baik, memiliki bertanggung jawab, visioner dan berkeinginan untuk maju, dan mantap dalam menjalani profesi.

Tabel 14 Kekuatan "Butir Pernyataan/Pertanyaan” terhadap Skill dan Interest

\begin{tabular}{lcccccc}
\hline \multirow{2}{*}{$\begin{array}{c}\text { Skor Butir Pernyataan } \\
\text { Indikator Skill dan } \\
\text { Interest }\end{array}$} & & & & & \multicolumn{3}{c}{ Test Value $=0$} \\
\cline { 2 - 7 } & $\mathrm{t}$ & $\mathrm{df}$ & $\begin{array}{c}\text { Sig. } \\
\text { (2-tailed) }\end{array}$ & $\begin{array}{c}\text { Mean } \\
\text { Difference }\end{array}$ & $\begin{array}{c}\text { Lonfidence Interval of } \\
\text { the Difference }\end{array}$ \\
\hline Skill-6 & $\mathbf{7 9 . 7 0}$ & 77 & .000 & 4.205 & 4.10 & Upper \\
\hline Skill-7 & 64.45 & 77 & .000 & 3.987 & 3.86 & 4.31 \\
\hline Skill-8 & $\mathbf{6 7 . 5 8}$ & 77 & .000 & 4.167 & 4.04 & 4.29 \\
\hline Skill-9 & $\mathbf{7 8 . 6 0}$ & 77 & .000 & 4.218 & 4.11 & 4.32 \\
\hline Interest-15 & $\mathbf{7 5 . 3 5}$ & 77 & .000 & 4.372 & 4.26 & 4.49 \\
\hline Interest-16 & 66.04 & 77 & .000 & 4.103 & 3.98 & 4.23 \\
\hline Interest-17 & $\mathbf{7 1 . 6 1}$ & 77 & .000 & 4.269 & 4.15 & 4.39 \\
\hline
\end{tabular}

Sumber: data primer diolah $\mathrm{N}=26,2018$

Kepemilikan skill dan interest oleh Jacalyn E. Bryan ${ }^{24}$ lebih ditekankan pada aspek penguasaan ilmu pengetahuan literasi informasi dan pemikiran kritis dalam pendidikan tinggi. Hal ini dirasa penting bahwa pustakawan akademik yang memberikan instruksi memiliki keterampilan yang diperlukan terkait dengan tanggung jawab mereka. Dari hasil riset yang dilakukan Bryan ini menguraikan, bahwa profesi untuk instruksi pustakawan dan koordinator mencakup dua belas kategori keterampilan yang dapat berfungsi sebagai ukuran kemampuan pustakawan sebagai instruktur. Pada penelitian ini, Bryan bermaksud menguji bagaimana pustakawan akademik

${ }^{24}$ Jacalyn E.Bryan. 2016. The Preparation of Academic Librarians Who Provide Instruction: A Comparison of First and Second Career Librarians. The Journal of Academic Librarianship Volume 42, Issue 4, July 2016, Pages 340-354 
merasa mereka telah siap untuk memberikan instruksi dengan menentukan sejauh mana pengalaman kerja sebelumnya (khususnya "karir pertama") mungkin memiliki dampak pada kemampuan mereka untuk melaksanakan tanggung jawab mengajar mereka dan untuk memeriksa sejauh mana gelar MLS telah mempersiapkan mereka di bidang instruksi. Sebuah survei dikirim ke empat perpustakaan Listservs yang menghasilkan 608 responden. Hasil menunjukkan bahwa pustakawan yang memiliki karir lain sebelum menjadi pustakawan akademik yang memberikan instruksi merasa bahwa mereka lebih siap untuk memberikan instruksi daripada mereka yang tidak memiliki karir sebelumnya. Lebih jauh lagi, tanggapan pustakawan ini tampaknya menunjukkan bahwa untuk sebagian besar kategori keterampilan, pengalaman kerja sebelumnya memberi mereka tingkat persiapan yang lebih besar daripada pendidikan MLS mereka.

Kemampuan berkomunikasi merupakan faktor yang menentukan terhadap kompetensi pustakawan dalam mengembangkan profesi sehingga dapat tercapai karir secara maksimal. Hal ini didukung oleh Liat Klain-Gabbay dan Snunith Shoham ${ }^{25}$ yang menyebutkan, bahwa komunikasi akademis bagi pustakawan perguruan tinggi umumnya dapat diterima di kalangan para sarjana ilmu perpustakaan dan informasi dan pustakawan perguruan tinggi dapat berpotensi membantu senat fakultas dengan proses komunikasi ilmiah formal dan informal. Namun, tidak jelas sampai sejauh mana senat fakultas dan pustakawan perguruan tinggi memang menyadari potensi ini dan mewujudkannya di lapangan. Setelah wawancara dengan 20 anggota senat fakultas dan 15 pustakawan perguruan tinggi yang dipekerjakan oleh universitas atau akademi di Lebanon, kuesioner dibangun dan dikirim ke 191 anggota senat fakultas dan 50 pustakawan. Analisis kualitatif dan kuantitatif mengungkapkan bahwa baik anggota senat fakultas dan pustakawan percaya bahwa pustakawan perguruan tinggi berpotensi mampu berkontribusi pada proses komunikasi ilmiah. Namun, anggota senat fakultas mempunyai harapan yang lebih terhadap pustakawan agar pustakawan senantiasa

${ }^{25}$ Liat Klain-Gabbay \& Snunith Shoham. Scholarly communication and academic librarians. Library \& Information Science Research Volume 38, Issue 2, April 2016, Pages 170-179 
terlibat dalam komunikasi ilmiah. Menjembatani kesenjangan ini, misalnya dengan memeberikan identitas sebagai "pustakawan peneliti" yang dapat berkontribusi pada peningkatan keterlibatan pustakawan perguruan tinggi dalam proses komunikasi ilmiah, yang akan menguntungkan baik bagi anggota senat fakultas maupun perpustakaan perguruan tinggi.

Kemampuan menjalin kerjasama bagi pustakawan dalam berkarir merupakan bagian/unsur dari kompetensi yang ditemukan dalam riset ini. Temuan ini mendapatkan dukungan dari Eglè Staniškienè dan Živilè Stankevičiūtè ${ }^{26}$, yang menyatakan bahwa jumlah organisasi yang menempatkan isu keberlanjutan dalam agenda strategis telah berkembang dalam beberapa tahun terakhir. Meskipun pembangunan berkelanjutan semakin penting, diskusi tentang langkah-langkah keberlanjutan terus berlanjut. Dimensi lingkungan dan ekonomi dapat lebih mudah dievaluasi dengan indikator kuantitatif yang dinyatakan secara jelas. Pengukuran keberlanjutan sosial membutuhkan keseimbangan antara indikator kuantitatif dan kualitatif. Selain itu, masih ada beberapa ambiguitas seputar keberlanjutan sosial yang sebenarnya. Tampaknya pada dasarnya determinan elemen "sosial" bergantung pada kerangka kerja yang mendasarinya. Namun, sebagian besar kerangka pengukuran yang ada tidak sepenuhnya membahas perspektif karyawan. Untuk menjembatani kesenjangan ini, penelitian ini bertujuan untuk memperkuat kerangka kerja untuk mengukur keberlanjutan sosial dari perspektif karyawan. Nilai ilmiah dari penelitian ini adalah kontribusi literatur pengukuran keberlanjutan sosial dengan mengidentifikasi perspektif karyawan. Kerangka yang diusulkan untuk pengukuran keberlanjutan sosial mencakup enam dimensi: partisipasi karyawan, kerja sama karyawan, peluang yang setara, pengembangan karyawan, kesehatan dan keselamatan, dan kemitraan eksternal. Untuk mencapai tujuan makalah, dua metode diterapkan: wawancara dengan manajer lini dan survei karyawan. Studi ini dilakukan dalam organisasi yang berkomitmen CSR,

${ }^{26}$ Eglè Staniškienè \& Živilè Stankevičiūtè. 2018. Social sustainability measurement framework: The case of employee perspective in a CSR-committed organisation. Journal of Cleaner Production Volume 188, 1 July 2018, Pages 708-719 
yang merupakan anggota Asosiasi Bisnis Bertanggung Jawab Lithuania. Temuan mengungkapkan beberapa perbedaan dalam sikap karyawan mengenai praktik keberlanjutan sosial. Kondisi kesehatan dan keselamatan diungkapkan sebagai yang paling penting dalam hal keberlanjutan sosial. Temuan ini juga menyarankan memasukkan perspektif karyawan ketika mengukur keberlanjutan sosial. Studi ini menunjukkan keterlibatan vital karyawan dalam evaluasi keberlanjutan sosial suatu organisasi.

Konsep pembangunan berkelanjutan membahas dimensi ekonomi, lingkungan dan sosial sebagai bagian integral. Sampai saat ini, keberlanjutan sosial kurang mendapat perhatian di bidang pembangunan berkelanjutan. Selain itu, keberlanjutan sosial menghadapi banyak tantangan terkait keragaman definisi, dimensi dan kerangka pengukuran. Tampaknya semua penulis mendapatkan definisi mereka sendiri berdasarkan perspektif penelitian. Karena konotasi multi-segi dari kata 'sosial', dimensi keberlanjutan sosial mencakup berbagai rangkaian tema. Secara khusus, perdebatan tentang pengukuran keberlanjutan sosial muncul ketika menerapkan kerangka kerja pengukuran keberlanjutan terpadu (misalnya, GRI atau UNCSD) atau kerangka kerja yang hanya ditujukan untuk keberlanjutan sosial. Dalam makalah ini, tinjauan singkat tentang beberapa kerangka telah disajikan dengan memberikan deskripsi singkat dan keuntungan dan kerugian utama. Tinjauan ini menunjukkan bahwa dimensi keberlanjutan sosial, kriteria dan indikator sebagian besar dibangun dari informasi statistik, yang umumnya diperoleh dari sumber-sumber publik. Selain itu, biasanya kerangka pengukuran yang ada tidak sepenuhnya membahas perspektif karyawan. Oleh karena itu, untuk menjembatani kesenjangan ini, studi ini menyediakan kerangka kerja untuk mengukur keberlanjutan sosial dari perspektif karyawan. Studi ini berpendapat untuk perspektif karyawan dalam pengukuran keberlanjutan sosial, sebagai karyawan adalah aset utama organisasi. Kerangka yang diusulkan mengandung enam dimensi: partisipasi karyawan, kerja sama karyawan, kesempatan yang sama, pengembangan karyawan, kesehatan dan keselamatan, dan kemitraan eksternal. Semua dimensi konsisten dengan dimensi yang ada dalam GRI, UNCSD dan kerangka 
pengukuran lainnya. Selain itu, dimensi yang diusulkan sejalan dengan praktik inti HRM. Berdasarkan kerangka teoritis yang diusulkan, masukan karyawan ke dalam keputusan yang terkait dengan organisasi dan tempat kerja (partisipasi); kerja tim dan berbagi pengalaman dengan rekan kerja (kerja sama); praktik ketenagakerjaan yang adil (kesempatan yang setara); program pelatihan karyawan, mentoring, praktik pembelajaran seumur hidup (pengembangan); dan kondisi kesehatan dan keselamatan di tempat kerja sangat penting untuk keberlanjutan sosial dari perspektif karyawan.

Rasa bertanggung jawab merupakan unsur lain dari kompetensi yang menjadikan modal bagi pustakawan dalam menjalani karirnya. Hal ini selaras dengan studi yang dilakukan oleh Andrew Dawson dan Pamm Phillips $^{27}$ yang menytakan bahwa pengembangan karir sangat penting untuk keberhasilan individu, organisasi, dan industri. Dengan demikian, dalam banyak profesi ada proses pengembangan karir yang ditentukan dan didukung oleh kebijakan hukum dan kelembagaan yang mendorong praktik manajerial. Meskipun ada minat yang berkelanjutan dan rasa tanggung jawab dalam memahami pengembangan karir untuk atlet dan membangun strategi manajerial untuk membantu dalam proses, ada sedikit pengetahuan empiris tentang pengembangan karier pelatih, dan bagaimana manajemen dapat membantu dalam prosesnya. Tujuan dari penelitian ini adalah untuk mengeksplorasi cara di mana wacana kebijakan olahraga dan agenda berdampak pada pengembangan karier dan rasa tanggung jawab pelatih. Studi ini menunjukkan bahwa karir pelatih bukan bagian dari wacana kebijakan meskipun peran penting kesuksesan mereka dalam kinerja atlet, pengembangan karir dan pengembangan organisasi olahraga. Pelatih adalah manajer kinerja utama dalam olahraga, namun mereka diabaikan oleh pembuat kebijakan olahraga dan manajer ketika mempertimbangkan pengembangan tenaga kerja olahraga. Dari hasil riset ini dapat diambil pelajaran, dimana pustakawan memiliki rasa tanggung jawab kepada institusi, pemustaka, dan diri sendiri demi tercapainya karir yang maksimal.

\footnotetext{
${ }^{27}$ Andrew Dawson \& Pamm Phillips. Coach career development: Who is responsible? Sport Management Review Volume 16, Issue 4, November 2013, Pages 477-487
} 
Memiliki visioner dan berkeinginan untuk maju merupakan modal kuat bagi pustakawan dalam barkarir. Hasil ini didukung oleh Fadime Çınar \& Ayça $\operatorname{Kaban}^{28}$ yang menyatakan bahwa indikator visioner menyangkut: jiwa kepemimpinan visioner; berorientasi pada tindakan, berpikir visioner, menggambarkan masa depan, bersikap terbuka terhadap perubahan.

Faktor-faktor yang mempengaruhi seseorang memiliki perasaan senang dan mantap dalam menjalani profesi menurut Yipeng Tang ${ }^{29}$ yang mengambil kasus profesi guru pedesaan di Cina menjelaskan bahwa: Pertama, premi upah untuk guru pedesaan relatif terhadap guru perkotaan dan profesi komparatif lainnya harus ditempatkan pada inti dari pembuatan kebijakan. Menurut temuan penelitian kami, tingkat upah relatif, daripada tingkat upah absolut, memainkan peran kunci dalam menentukan guru pedesaan. Oleh karena itu, bagi para guru pedesaan yang bekerja di lingkungan yang penuh tantangan, adalah hak istimewa mereka untuk menerima sejumlah besar premi upah atas rekan-rekan mereka di perkotaan dan profesi komparatif lainnya. Bonus kerja dan tunjangan kesulitan telah terbukti menjadi strategi yang efektif di beberapa negara maju (Clotfelter dkk., 2008) dan negara-negara berkembang (Pugatch and Schroeder, 2014). Di Cina, karena banyaknya jumlah guru pedesaan dan anggaran pendidikan pemerintah daerah yang terbatas, komitmen untuk menjaga gaji guru lebih tinggi daripada pegawai negeri setempat belum sepenuhnya tercapai.

Kedua, menciptakan lebih banyak peluang bagi guru-guru desa untuk terlibat dalam manajemen sekolah dapat menjadi strategi yang efektif untuk meningkatkan SWB mereka. Penelitian kami menemukan bahwa pengaruh posisi administratif pada guru pedesaan SWB adalah signifikan dan bahkan mengerdilkan efek dari senioritas. Ini menyiratkan bahwa strategi tradisional untuk mempercepat laju promosi guru pedesaan

${ }^{28}$ Fadime Çınar \& Ayça Kaban. Conflict Management and Visionary Leadership: An Application in Hospital Organizations. Procedia - Social and Behavioral Sciences Volume 58, 12 October 2012, Pages 197-206

${ }^{29}$ Yipeng Tang. What makes rural teachers happy? An investigation on the subjective wellbeing (SWB) of Chinese rural teachers. International Journal of Educational Development Volume 62, September 2018, Pages 192-200 
mungkin tidak bekerja seefektif memberdayakan mereka untuk memiliki suara mereka dalam keputusan sekolah mulai dari kepegawaian, penilaian siswa, hingga perencanaan kurikulum. Sebenarnya, bukti serupa diberikan dalam penelitian terbaru dari Hallinger dan Liu (2016), yang menegaskan bahwa kepemimpinan yang berpusat pada pembelajaran menghasilkan efek positif yang signifikan pada kondisi psikologis guru (misalnya kepercayaan dan agensi) dan bahwa efek ini bahkan lebih kuat untuk guru pedesaan.

Ketiga, bantuan yang sesuai untuk membangun keluarga yang harmonis dapat menjadi strategi jangka panjang untuk meningkatkan guru pedesaan SWB dan mempertahankan guru yang berkualitas. Guru pedesaan biasanya bekerja di lingkungan yang menantang yang ditampilkan oleh infrastruktur dan layanan dasar yang tidak memadai, yang menciptakan penghalang bagi mereka untuk membangun hubungan keluarga yang harmonis dengan pasangan dan anak-anak mereka. Untuk tujuan ini, adalah tanggung jawab pemerintah daerah untuk mengatasi kebutuhan keluarga guru pedesaan melalui penyediaan dukungan perumahan atau layanan penitipan anak. Selain itu, bagi pasangan guru yang bekerja di kabupaten terpisah, kebijakan yang fleksibel memungkinkan transfer guru antar daerah harus didorong.

\section{Kesimpulan Dan Saran}

\section{Kesimpulan}

a. Persepsi responden terhadap budaya organisasi Perpustakaan UII pada kategori sangat tinggi dengan skor persepsi 81,76. Variabel budaya organisasi ini memiliki 7 indikator yang masing-masing indikator memiliki kekuatan, antara lain: indikator kreatif dan mampu berspekulasi dalam kategori sangat tinggi (80.8), peduli terhadap profesi dalam kategori tinggi $(79,7)$, fokus terhadap prestasi dalam kategori sangat tinggi (83.5), fokus kepada personal dalam kategori sangat tinggi (82), fokus kepada satuan kerja/kelompok dalam kategori sangat tinggi (80.8), sifat agresif dalam kategori sangat tinggi $(83,6)$, dan kemantapan/ kenyamanan dalam 
kategori tinggi $(81,92)$. Kekuatan tertinggi terletak pada indikator sifat agresif sebesar 83,6 dan terendah pada indikator peduli terhadap profesi senilai 79,7. Sementara itu dari indikator sifat agresif tersebut terdiri dari 7 butir pernyataan, setelah dilakukan perhitungan dapat diketahui hasilnya bahwa, dari indikator sifat agresif ini memiliki 5 kekuatan aspek terbesar antara lain meliputi: seorang pustakawan dalam melaksanakan tugas penuh dengan tanggung jawab $(75,22 \%)$, bekerja sesuai SOP yang ada $(56,26 \%)$, berperilaku sesuai dengan aturan dan norma yang ada $(64,16 \%)$, senang berbagi pengetahuan $(81,24 \%)$, dan selalu giat bekerja meskipun tidak ada yang mengawasi $(71,61 \%)$. Dari hasil kajian ini dapat disimpulkan bahwa kekuatan terbesar dari masing-masing indikator pada variabel budaya organsisasi Perpustakaan UII Yogyakarta terletak pada aspek sifat agresif, yang berarti bahwa seorang pustakawan didalam menjalankan profesinya perlu penuh tanggung jawab, bekerja sesuai dengan prosedur, berperilaku sesuai dengan aturan dan norma, tidak pelit terhadap ilmu yang dimiliki, dan giat bekerja walaupun tidak sedang diawasi.

b. Persepsi responden terhadap kompetensi Pustakawan UII dalam kategori dengan skor 84,25. Variabel kompetensi memiliki 6 indikator, masingmasing indikator memiliki kekuatan, antara lain: indikator minat dengan skor 87,4, disusul berturut-turut indikator kemampuan sebesar 86.7, indikator pemahaman sebesar 83,5, indikator knowledge sebesar 82.6, indikator nilai sebesar 81.9, dan indikator sikap dengan skor sebesar 81,5. Dari hasil hitungan ini dapat disimpulkan bahwa kekuatan terbesar dari masing-masing indikator pada variabel kompetensi pustakawan UII Yogyakarta terletak pada aspek skill dan minat/interest yang tinggi, yang berarti bahwa seorang pustakawan didalam menjalankan profesinya harus mampu menjalin kerjasama, mampu berkomunikasi dengan baik, memiliki rasa tanggung jawab, visioner dan berkeinginan untuk maju, dan mantap dalam menjalani profesi.

c. Pengaruh budaya organisasi (X) terhadap kompetensi (Y) dibuktikan dengan pernyataan bahwa persepsi pustakawan UII Yogyakarta menge- 
nai budaya organisasi $(\mathrm{X})$ mempunyai pengaruh signifikan terhadap kompetensi dengan angka substansial $(0,014<0,05)$, artinya menerima hipotesis penelitian ini. Hasil kajian telah dilaksanakan lewat analisis data secara simultan yang hasilnya ditampilkan pada Tabel 9 dan telah dijelaskan bahwa pengaruh langsung persepsi pustakawan UII Yogyakarta antara variabel budaya organisasi (X) terhadap variabel kompetensi (Y) senilai 0,478 dengan derajat substansial senilai 0,014. Hal ini membuktikan bahwa ada pengaruh yang positif dan substansial antara budaya organisasi (X) terhadap kompetensi (Y). Hasil ini memiliki arti bahwa budaya organisasi yang dipersepsikan pada pustakawan merupakan fenomena yang positif (baik, tinggi), maka persepsi pustakawan terhadap kompetensi juga akan baik (tinggi).

\section{Saran}

a. Secara empiris, responden memberikan persepsi bahwa ada titik kelemahan yang mendasar terhadap Budaya Organisasi Perpustakaan UII Yogyakarta, yakni terletak pada aspek kepedulian terhadap profesi pustakawan. Kelemahan yang perlu perbaikan adalah menyangkut:

1) Perpustakaan perlu lebih menaruh perhatian dalam memberikan informasi kepada pustakawan terhadap hal penting/vital dalam tugas kantor.

2) Informasi standar mutu perpustakaan terhadap hasil pekerjaan.agar disampaikan secara lebih jelas.

3) Perpustakaan perlu menekankan akan pentingya dalam mencapai tujuan lembaga secara detail kepada para pustakawan.

b. Sementara itu dari hasil kajian ini ditemukan, bahwa responden memberikan persepsi bahwa ada titik kelemahan yang mendasar terhadap Kompetensi Pustakawan UII terdapat pada aspek pemahaman dan sikap terhadap profesi. Kelemahan yang perlu perbaikan adalah menyangkut:

1) kemampuan memberikan ide yang baik dalam bekerja.

2) dapat berpikir kreatif dalam melaksanakan pekerjaan. 
3) dapat menyelesaikan pekerjaan sesuai dengan prosedur.

4) selalu hadir tepat waktu.

5) dapat bekerja sama, memenuhi aturan-aturan yang berlaku di dalam melakukan pekerjaan.

\section{DAFTAR PUSTAKA}

Ahmed, Shuaib. dkk 2014. Organizational Culture and its Impact on Employee Career Progression in Public Sector Organizations in Pakistan. IBT Journal of Business Studies (Formerly Journal of Management \& Social Sciences) Vol. 10, No. 2, (Fall 2014) 56-70

Bryan, Jacalyn E. 2016. The Preparation of Academic Librarians Who Provide Instruction: A Comparison of First and Second Career Librarians. The Journal of Academic Librarianship Volume 42, Issue 4, July 2016, Pages 340-354

Çinar, Fadime \& Kaban, Ayça. Conflict Management and Visionary Leadership: An Application in Hospital Organizations. Procedia Social and Behavioral Sciences Volume 58, 12 October 2012, Pages 197-206

Dawson, Andrew \& Phillips, Pamm. Coach career development: Who is responsible? Sport Management Review Volume 16, Issue 4, November 2013, Pages 477-487

Deal, Terrence E. and Alland A. Kennedy. 2001. Corporate Cultures: The Rites and Rituals of Corporate Life. New Jersey: Addison-Wesley Publishing Company Inc.,

Dessler, Gary. 2000. Human Resource Management $8^{\text {th }}$, New Jersey: Prentice Hall, Inc.

Hofstede, Jan G. 2005. Cultures and Organizations (Sofware of The Mind): Intercultural Cooperation and its Importance for Survival. New York: McGraw-Hill.

Holder, Sara \& Lannon, Amber. 2018. Managing the Multigenerational Librarian Workforce. Elsevier Ltd. All rights reserved on line, hal 21-35. 
Jeong-Sil Choi, \& Ji-Soo Kim. 2018. Effects of cultural education and cultural experiences on the cultural competence among undergraduate nursing students. Nurse Education in Practice 29 (2018) 159-162.

Jusuf, A. A. 1993. Auditing Pendekatan Terpadu Edisi kelima. Jakarta: Salemba Empat.

Klain-Gabbay, Liat \& Shoham, Snunith. Scholarly communication and academic librarians. Library \& Information Science Research Volume 38, Issue 2, April 2016, Pages 170-179

Moeheriono. 2010. Pengukuran Kinerja Berbasis Kompetensi. Bogor: Ghalia Indonesia.

Muchlas, Makmuri. 2005. Perilaku Organisasi. Yogyakarta: Gadjah Mada University Press.

Perpusnas RI. 2011. Standar Nasional Perpustakaan (SNP) Perguruan Tinggi Tahun 2011. Jakarta: Perpusnas RI.

Perpusnas RI, 2012. Standar Kompetensi Kerja Nasional Indonesia (SKKNI) Nomor 83 Tahun 2012 Bidang Perpustakaan. Jakarta: Perpusnas RI.

Quran Surat Ali Imran ayat 103.

Robbins, Stephen P. 2009. Organizational Behavior, 13rd ed. New Jersey: Prentice Hall.

Robbins, Stephen P. 2001. (terjemahan Tim Indeks), Perilaku Organisasi, Edisi 9, Jilid 2. Jakarta: PT Indeks Kelompok Gramedia.

Schein, E.H. 1985. Organizational Culture and Leadership. San Francisco: Jossey Bass Inc.

Simamora, H. 2002. Auditing 1. Yogyakarta: UPP AMP YKPN.

Staniškienè, Eglè \& Stankevičiūtè, Živilè. 2018. Social sustainability measurement framework: The case of employee perspective in a CSRcommitted organisation. Journal of Cleaner Production Volume 188, 1 July 2018, Pages 708-719

Supardi. 2006. Pengaruh Budaya Organisasi terhadap Keadilan Distributif dan Keadilan Prosedural, serta Produktivitas Kerja Pegawai Hotel Berbintang di Daerah Istimewa Yogyakarta. Disertasi. Surabaya: 
Program Pascasarjana Airlangga.

Surfeliya, F., Andreas, \& Yusralaini. 2014. Professional Influence Skeptisisme, Competention, Audit Situation, Audit Ethics, Experience and Expertise Make an audit of to Accuracy of Audit Opinion by Auditor BPK. JOM FEKON, 1(2), 1-15.

Sustrisno, Edi Iswanto. 2011. Manajemen Sumber Daya Manusia. Jakarta: Kencana.

Tika, Pabundu. 2006. Budaya Organisasi dan Peningkatan Kinerja Perusahaan. Jakarta: PT. Bumi Aksara.

Yipeng Tang. What makes rural teachers happy? An investigation on the subjective well-being (SWB) of Chinese rural teachers. International Journal of Educational Development Volume 62, September 2018, Pages 192-200

Zangiski, Marlene Aparecida da Silva Goncalves; Edson Pinheiro de Lima, \& Sergio E. Gouvea da Costa. 2013. Organizational competence building and development: Contributions to operations management. Int. J.Production Economics 144 (2013) 76-89 